\title{
Contribution to the scythridid fauna of southern Buryatia, with description of seven new species (Lepidoptera: Scythrididae)
}

\author{
Kari Nupponen
}

\begin{abstract}
Nupponen, K. 2003: Contribution to the scythridid fauna of southern Buryatia, with description of seven new species (Lepidoptera: Scythrididae). — Entomol. Fennica 14: 25-45.

A list of 26 species embracing 673 specimens of the family Scythrididae collected during 13.-29.VI.2002 from southern Buryatia is presented. Seven new species are described: Scythris erinacella sp. n., S. gorbunovi sp. n., S. hamardabanica sp. n., S. malozemovi sp. n., S. ninae sp. n., S. potatorella sp. n. and $S$. sinevi sp. n. Two unknown species are mentioned but not described because only females are available. In addition, S. penicillata Chrétien, 1900 is reported as new for Russia, S. emichi (Anker, 1870) as new for the Asiatic part of Russia and seven further species as new for the Baikal region. The known distribution range of each species is given as well as further notes on some poorly known taxa.
\end{abstract}

Kari Nupponen, Miniatontie 1 B 9, FIN-02360 Espoo, Finland

Received 30 October 2002, accepted 21 January 2003

\section{Introduction}

The Republic of Buryatia is located on the southern and southeastern shores of Lake Baikal. Characteristic features of the southern part of that region are mountain ranges: East Sayan Mountains in the west and Hamar Daban Mountains in the east, the latter dividing the region into a taiga forest zone in the north and a steppe zone in the south. The mountains, up to $2000 \mathrm{~m}$ a.s.l., are covered by conifer forests, and mountain tundra is present only at the highest elevation. The steppes mainly exist in a rather restricted area in the valley of the River Selenga and its subsidiaries, and very sparsely in Irkut valley in East Sayan. The lowest elevation of the region is at the shore of the Lake Baikal (456 m), with the highest one being in the Sayan Mountains (3491 m).

The scythridid fauna of southern Buryatia is poorly known. The published reports (Bengtsson
\& Liška 1996, Sinev 2001) concern occasionally collected single specimens, and no systematic investigations of scythridids have been made in the region. The present article is based on material collected by the author during 13.-29.VI.2002 in southern Buryatia.

\section{The investigated area, material and methods}

The investigated area is situated between $50-52^{\circ} \mathrm{N}$ and 100 $108^{\circ} \mathrm{E}$, mainly in the valley of the River Selenga and southern foothills of Hamar Daban Mountains, but also in Irkut valley in the East Sayan Mountains. The material, comprising 673 pinned specimens of Scythrididae, was collected by sweeping and netting during daytime. In addition, hundreds of specimens were observed but not collected, because they were easily determined in the field. Several species occurred in large numbers and it was possible to col- 


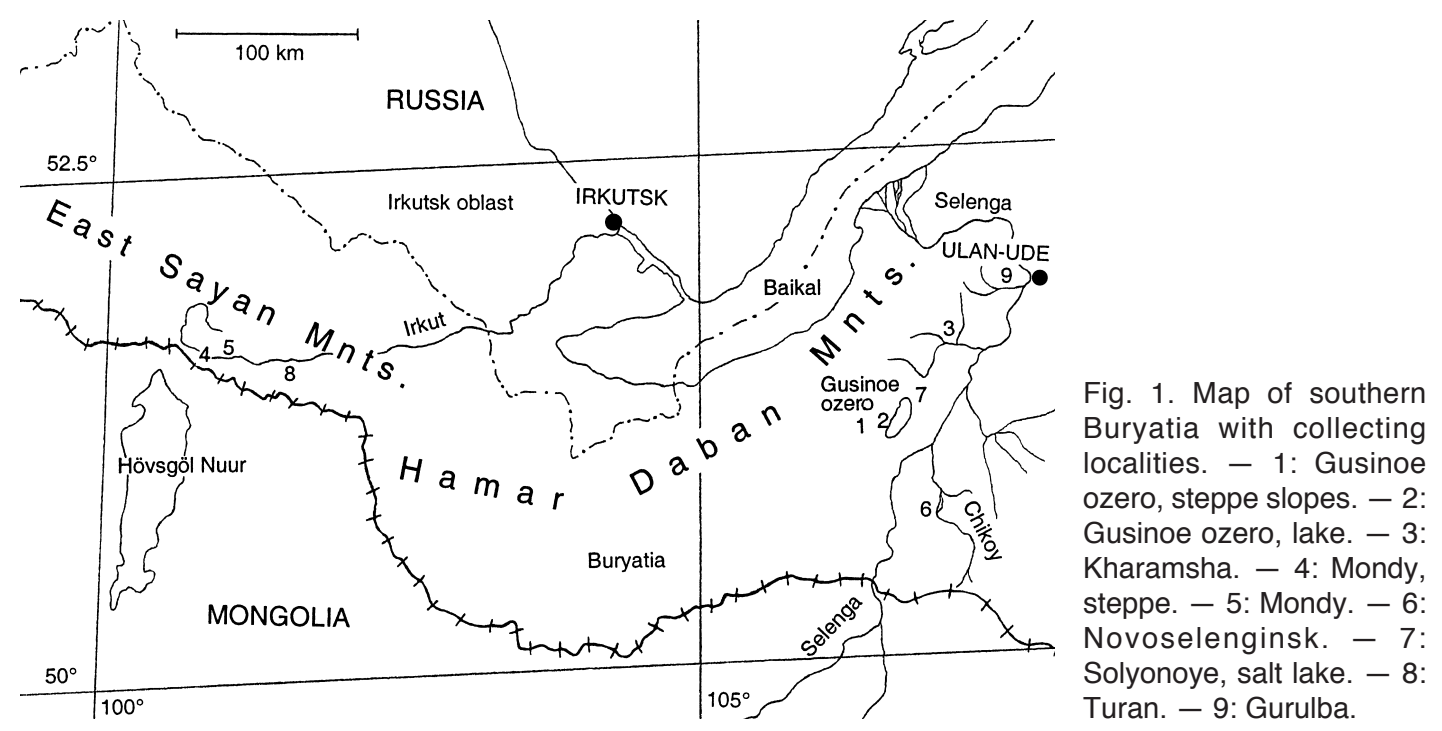

lect them without limits. Seven of the recorded species are previously unknown, and they are described in this paper. The collected material is generally deposited in the collection of the author.

\section{Collecting sites}

The collecting sites and dates are mentioned below. The number given to each of the localities is connected to that on the map (Fig. 1).

- 1: Russia, S-Buryatia, $51^{\circ} 11-13^{\prime} \mathrm{N} 106^{\circ} 10$ $12^{\prime} \mathrm{E}, 700$ m, Hamar Daban Mountains, Murtoy river, Gusinoe ozero village $6 \mathrm{~km} \mathrm{NW}$. 19.-22.VI.2002. A foothill region of Hamar Daban Mountains. Rocky steppe slopes and forest steppes (Fig. 2).

- 2: Russia, S-Buryatia, $51^{\circ} 09^{\prime} \mathrm{N} 106^{\circ} 16^{\prime} \mathrm{E}$, $550 \mathrm{~m}$, lake Gusinoe ozero. 18.VI.2002, 23.VI.2002. Dry Artemisia steppe on the shore of the lake.

- 3: Russia, S-Buryatia, $51^{\circ} 37^{\prime} \mathrm{N} 106^{\circ} 46^{\prime} \mathrm{E}$, 600 m, Hamar Daban Mountains, bolshoi Sanzheevka river, Kharamsha village $2 \mathrm{~km}$ W. 27.-28.VI.2002. A small, partly rocky steppe area at the foothills of Hamar Daban Mountains, surrounded by conifer forests (Fig. 3).

- 4: Russia, SW-Buryatia, $51^{\circ} 47-48^{\prime} \mathrm{N} 100^{\circ} 52-$ 55르, East Sayan Mountains, 1500 m, Mondy village $2 \mathrm{~km}$ WNW. 13.VI.2002. A rocky steppe slope.
- 5: Russia, SW-Buryatia, 51 ${ }^{\circ} 47-48^{\prime} \mathrm{N} 100^{\circ} 55-$ 58 'E, East Sayan Mountains, 1450 m, Mondy village $2 \mathrm{~km}$ E. 13.-15.VI.2002. Conifer forest with restricted forest steppes.

- 6: Russia, S-Buryatia, 5058-59’ N 106 38 40’E, 550-600 m, Chikoy valley, Novoselenginsk village $10 \mathrm{~km}$ S. 23.-25.VI.2002. A sand dune region at the river valley, gradually passing into sandy steppe and rocky slopes with plenty of Artemisia and Thymus at higher elevations (Fig. 4).

- 7: Russia, S-Buryatia, 51 ${ }^{\circ} 28^{\prime} \mathrm{N} 106^{\circ} 33^{\prime} \mathrm{E}$, $600 \mathrm{~m}$, lake Solyonoye. 26.VI.2002. A small salt lake, surrounded by salt marshes and dry Artemisia steppes.

- 8: Russia, SW-Buryatia, East Sayan Mountains, $900 \mathrm{~m}$, Halagun river, Turan village $8 \mathrm{~km} \mathrm{W.16.VI.2002.} \mathrm{Mixed} \mathrm{forest} \mathrm{with}$ small meadows.

- 9: Russia, S-Buryatia, Ulan-Ude $10 \mathrm{~km} \mathrm{W,}$ near Gurulba village, 700 m. 29.VI.2002. Forest steppes and meadows.

\section{List of scythridid species}

The species are presented in alphabetic order as the family Scythrididae has not been revised and the relationships within the family are not fully understood. The grouping of the species inside the genus follows that of Bengtsson (1997a). The 


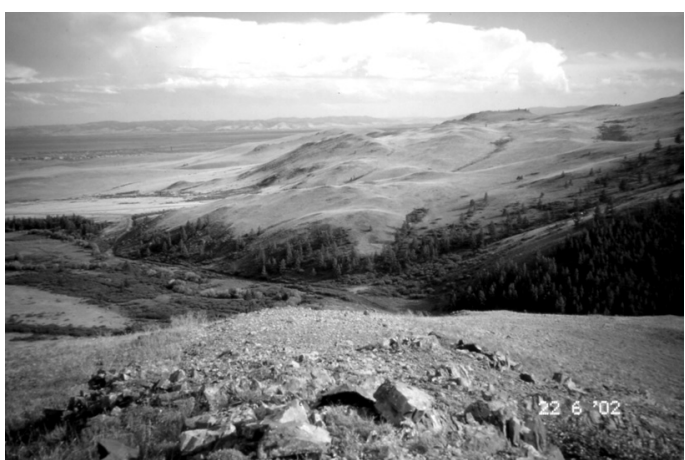

Fig. 2. Foothills of Hamar Daban Mountains near Gusinoe Ozero. The habitat of Scythris felixi Bgts. \& Sutter, S. hamardabanica sp. n., S. lativalvella Sinev, S. nitidella Sinev, S. potatorella sp. n., S. sibirella Sinev and S. sinevi sp. n.

known distribution for each species is given, as well as further notes on some poorly known taxa.

\section{Scythris braschiella (Hofmann, 1889)}

Russia, S-Buryatia, 5 $^{\circ} 11-13^{\prime} \mathrm{N} 106^{\circ} 10-12^{`} \mathrm{E}, 700 \mathrm{~m}$, Hamar Daban Mountains, Murtoy river, Gusinoe ozero village $6 \mathrm{~km}$ NW, forest steppe, 1 O' 19.VI.2002, K. Nupponen leg.

Distribution. Germany, Greece, Turkey, Poland, Russia (S Ural, Altai).

Remarks. The examination of further specimens from the Altai Mountains (Kuraiskaja step, 5 ơ $^{7}$ 13.VII.2001, K. Nupponen leg.) confirmed that the Altaian taxon is the true braschiella, despite its large size (see K. \& T. Nupponen 2001). The specimens from Buryatia and Altai are externally alike. This record extends the known distribution range of S. braschiella $1400 \mathrm{~km}$ to the east. New to the Baikal region.

\section{Scythris cassiterella (Snellen, 1884)}

Russia, SW-Buryatia, 51 ${ }^{\circ} 47-48^{`} \mathrm{~N} 100^{\circ} 55-58^{`} \mathrm{E}$, East Sayan Mountains, $1450 \mathrm{~m}$, Mondy village $2 \mathrm{~km}$ E, forest

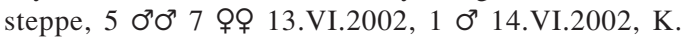
Nupponen leg.

Russia, S-Buryatia, $51^{\circ} 11-13^{`} \mathrm{~N} 106^{\circ} 10-12^{`} \mathrm{E}, 700 \mathrm{~m}$, Hamar Daban Mountains, Murtoy river, Gusinoe ozero village $6 \mathrm{~km} \mathrm{NW}$, forest steppe, 10 ơ $^{7} 12$ 우 19.VI.2002, $10^{7} 3$ 우 22.VI.2002, K. Nupponen leg.

Russia, S-Buryatia, $51^{\circ} 37^{\prime} \mathrm{N} 106^{\circ} 46^{\prime} \mathrm{E}, 600 \mathrm{~m}$, Hamar Daban Mountains, bolshoi Sanzheevka river, Kharamsha

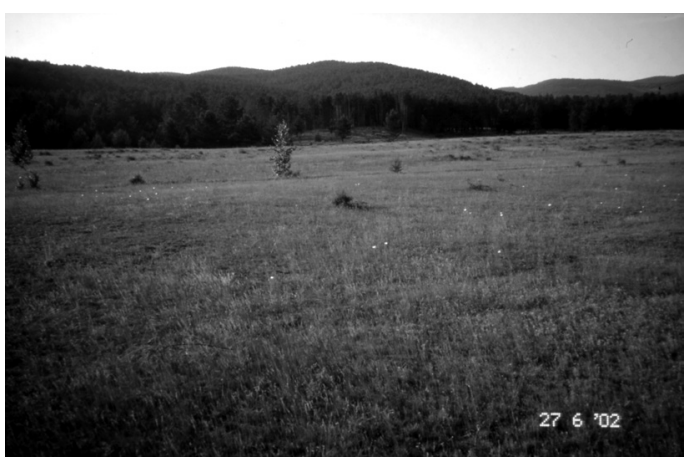

Fig. 3. Foothill steppe of Hamar Daban Mountains near Kharamsha village. The habitat of Scythris emichi (Ank.), S. hamardabanica sp. n., S. minorella Sinev, S. penicillata Chrét., S. potatorella sp. n. and S. sinevi sp. $\mathrm{n}$.

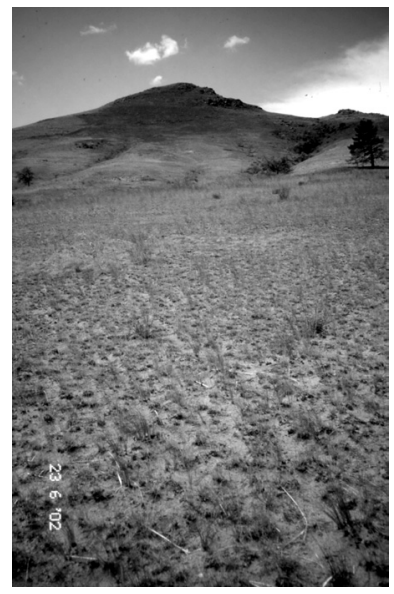

Fig. 4. Sandy steppe and rocky slopes in Chikoy valley near Novoselenginsk village. The habitat of $S$. erinacella sp. n., S. gorbunovi sp. n., $S$. hamardabanica sp. n., $S$. malozemovi sp. n., $S$. minorella Sinev, S. ninae sp. n., S. potatorella sp. n. and S. remexella K. Nupponen \& Kaitila.

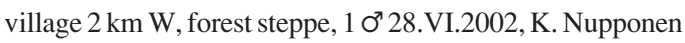
leg.

Russia, S-Buryatia, Ulan-Ude $10 \mathrm{~km} \mathrm{W,} \mathrm{near} \mathrm{Gurulba}$ village, meadow/steppe, 700 m, 8 O' $^{\prime \prime} 1$ \% 29.VI.2002, K. Nupponen leg.

Distribution. Russia (Altai, Tuva, Krasnojarskij kraj, Baikal region, Amur).

Remarks. Scythris baikalensis Bengtsson \& Liška, 1996 is a junior synonym of $S$. cassiterella (see Sinev 2001). The species is abundant in various kinds of steppe habitats. 


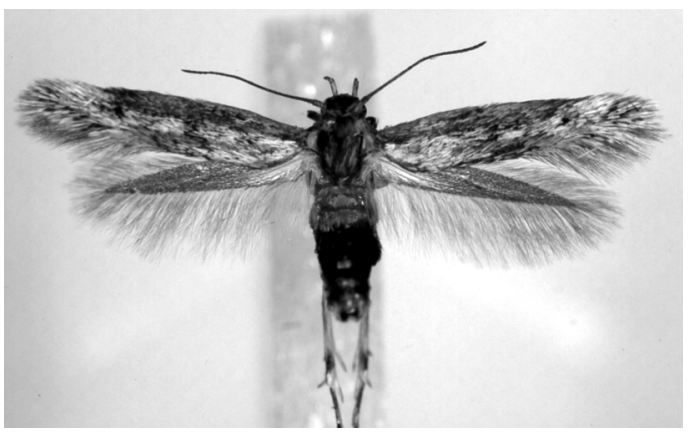

Fig. 5. Imago (holotype) of Scythris erinacella sp. $n$.

\section{Scythris emichi (Anker, 1870)}

Russia, S-Buryatia, $51^{\circ} 37^{\prime} \mathrm{N} 106^{\circ} 46^{\prime} \mathrm{E}, 600 \mathrm{~m}$, Hamar Daban Mountains, bolshoi Sanzheevka river, Kharamsha

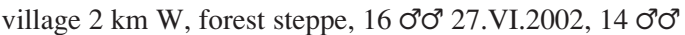
28.VI.2002, K. Nupponen leg.

Russia, S-Buryatia, Ulan-Ude $10 \mathrm{~km} \mathrm{W,} \mathrm{near} \mathrm{Gurulba}$ village, meadow/steppe, 700 m, 2 o $^{7} 0^{7}$ 29.VI.2002, K. Nupponen leg.

Distribution. Hungary, Latvia, Russia (S Ural). Recently recorded also in lower Volga region in the vicinity of Sarepta (Volgograd obl., Volgograd $80 \mathrm{~km}$ NW, near Ilovla village, 5 exx. 02.VI.2001, K. Nupponen leg.).

Remarks. These records extend the known distribution range of S. emichi $3300 \mathrm{~km}$ to the east. New to the Baikal region and Asian part of Russia. The host plant of the taxon is Gypsophila patrinii Ser. in Siberia.

\section{Scythris erinacella sp. n.}

Type material. Holotype: $\sigma^{7}$ (Fig. 5): Russia, SBuryatia, 5058-59’ ${ }^{\circ} 106^{\circ} 38-40^{\prime} \mathrm{E}, 550-600 \mathrm{~m}$, Chikoy valley, Novoselenginsk village $10 \mathrm{~km} \mathrm{~S}$, sand dunes/sandy steppe, 25.VI.2002, K. Nupponen leg. In coll. T. \& K. Nupponen. Paratypes $\left(8 \sigma^{7} \sigma^{7}\right)$ : Same data as holotype, except

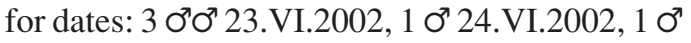
25.VI.2002. $30^{7} 0^{7}$ Russia, S-Buryatia, $51^{\circ} 09^{\prime} \mathrm{N}$ $106^{\circ} 16^{\prime} \mathrm{E}, 550 \mathrm{~m}$, lake Gusinoe ozero, steppe, 23.VI.2002, K. Nupponen leg. Genitalia slide: K. Nupponen prep. no. 1/03.X.2002 (ठ'). In coll. T. \& K. Nupponen.

Diagnosis. Externally S. erinacella sp. n. can be confused with many small, brown scythridids, for example S. hamardabanica sp. n., $S$.

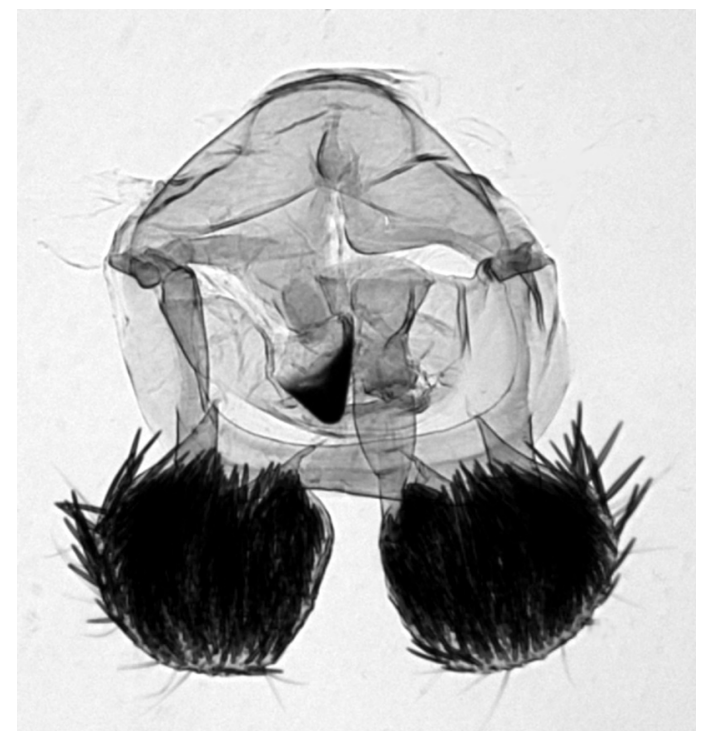

Fig. 6. Male genitalia of Scythris erinacella sp. n. (paratype).

malozemovi sp. n., S. gorbunovi sp. n., S. terekholensis Bengtsson, 1997 and some still undescribed taxa from Turkey. The male genitalia structure resembles that of S. terekholensis (see Remarks), but differs in details. The valva of $S$. erinacella is shorter with roundish posterior half, the shape of gnathos is different and the tergum VIII is triangular with more robust, sclerotized distal processes and weak lateral extensions.

Description. Wingspan 9.5-11.5 mm. Head and thorax dark brown mixed with pale brown scales. Antenna dark brown. Collar, tegula and neck tuft pale brown. Labial palp: segment I whitish brown, segment II pale brown, segment III fuscous mixed with dirty whitish scales. Haustellum whitish brown, basally darker. Forelegs and midlegs dark brown with few paler scales. Hindleg: femur whitish brown, distally with narrow dark brown ring; tibia pale brown, at 0.9 moderately broad, distinct dark brown ring; tarsus fuscous, outer surface and distal 1/3 darker. Abdomen dorsally dark brown, posterior margin of each segment paler; ventrally pale ochreous. Forewing pale brown with darker areas at dorsal margin, around fold, near costal margin at $1 / 3$ and $3 / 4$, and at apex; indistinct black spots in fold at $0.2,0.4$ and at cell end; white scales forming indistinct streak in fold from base to $2 / 3$; scattered white scales occur also more or less frequently at 


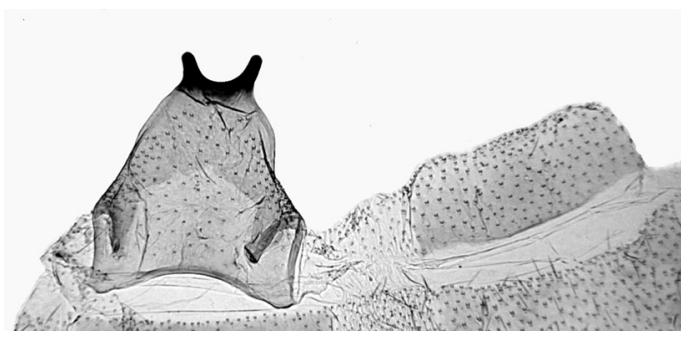

Fig. 7. Tergum VIII (left) and sternum VIII (right) of Scythris erinacella sp. n. (paratype).

basal $1 / 3$ of dorsal area and in apical $1 / 5$. Hindwing fuscous.

Male genitalia (Figs. 6-7). Uncus reduced. Gnathos thick, slightly asymmetrical, basally wide, terminally tapered with strongly sclerotized subtriangular portion at tip; tip blunt. Aedeagus thick, straight, basally enlarged. Valvae fused at base, spatular, posterior half roundish and covered with slender and strongly sclerotized pegs. Sternum VIII subrectangular. Tergum VIII subtriangular; posterior margin sclerotized with two thick, blunt processes; anterior margin concave; lateral extensions slightly asymmetrical, weakly sclerotized.

Female genitalia. Unknown.

Bionomy. The specimens were collected in late June in sandy steppes. The biology is unknown.

Distribution. Russia (S Buryatia).

Etymology. The species name refers to the roundish valvae covered with pegs, resembling back of a hedgehog (Erinaceus sp.).

Remarks. S. erinacella sp. n. is a close relative of S. terekholensis Bengtsson, 1997, a species described from Tuva ca. $500 \mathrm{~km}$ WSW of Irkutsk. Both taxa belong to the complex of species treated in Remarks of $S$. gorbunovi sp. n. (see below).

\section{Scythris felixi Bengtsson \& Sutter, 1996}

Russia, S-Buryatia, $51^{\circ} 11-13^{\prime} \mathrm{N} 106^{\circ} 10-12^{\prime} \mathrm{E}, 700 \mathrm{~m}$, Hamar Daban Mountains, Murtoy river, Gusinoe ozero village $6 \mathrm{~km} \mathrm{NW}$, forest steppe, $300^{7} \sigma^{7}$ 19.VI.2002, 14 O $^{7} \sigma^{7}$ 22.VI.2002, K. Nupponen leg.

Russia, S-Buryatia, 5058-59`N 106³8-40`E, 550-600 $\mathrm{m}$, Chikoy valley, Novoselenginsk village $10 \mathrm{~km} \mathrm{~S}$, sand dunes/sandy steppe, $10^{\top}$ 24.VI.2002, K. Nupponen leg.

Russia, S-Buryatia, 51 $37^{\circ} \mathrm{N} 106^{\circ} 46^{\prime} \mathrm{E}, 600 \mathrm{~m}$, Hamar Daban Mountains, bolshoi Sanzheevka river, Kharamsha

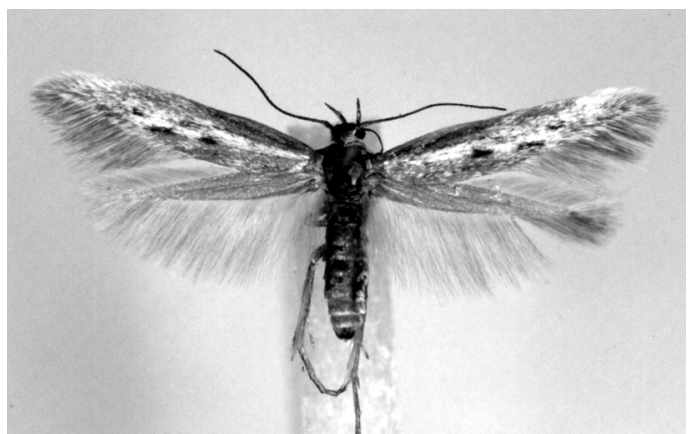

Fig. 8. Imago of Scythris felixi Bengtsson \& Sutter, 1996 (pale form).

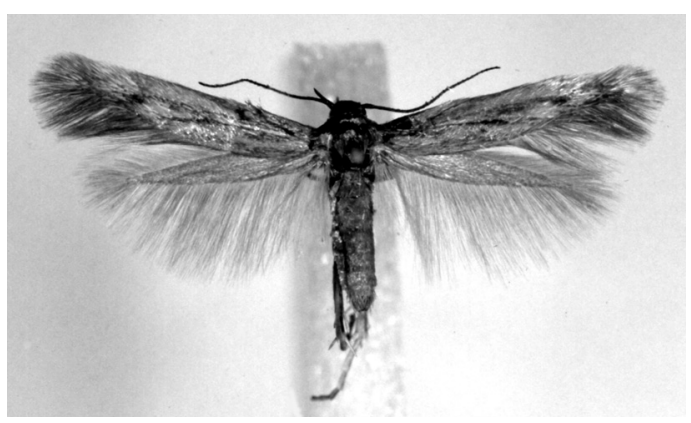

Fig. 9. Imago of Scythris felixi Bengtsson \& Sutter, 1996 (dark form).

village $2 \mathrm{~km} \mathrm{~W}$, forest steppe, 6 o $^{7} \sigma^{7} 27 . \mathrm{VI} .2002,60^{7} \sigma^{7}$ 28.VI.2002, K. Nupponen leg.

Distribution. Mongolia, Russia (Altai).

Remarks. S. felixi is an externally variable species. The ground colour of the forewings varies from pale greyish to blackish and the pattern from distinct to almost invisible (Figs. 8-9). The size of the moth varies and most of the Buryatian specimens are larger (wingspan 11-15 mm) than the type specimens from Mongolia. There seems to be some variation also in the male genitalia, especially in the shape of the subapical part of valva (Figs. 10-11). New to the Baikal region.

\section{Scythris gorbunovi sp. n.}

Type material. Holotype: $\sigma^{7}$ (Fig. 12): Russia, SBuryatia, 5058-59`N 106 38-40’E, 550-600 m, Chikoy valley, Novoselenginsk village $10 \mathrm{~km} \mathrm{~S}$, sand dunes/sandy steppe, 24.VI.2002, K. Nupponen leg. In coll. T. \& K. Nupponen. 


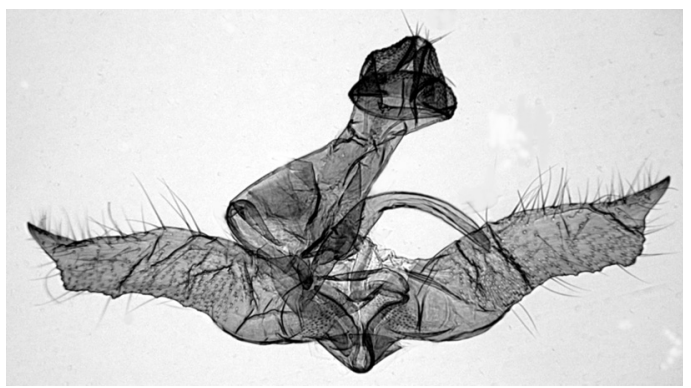

Fig. 10. Male genitalia of Scythris felixi Bengtsson \& Sutter, 1996.

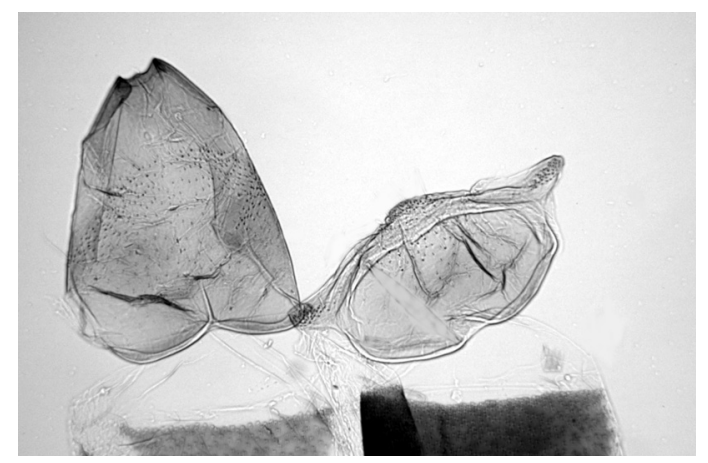

Fig. 11. Tergum VIII (left) and sternum VIII (right) of Scythris felixi Bengtsson \& Sutter, 1996.

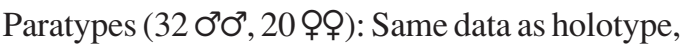
except for dates: $10^{\top} 23$. VI.2002, 19 Ơ $^{7} 18$ 우우

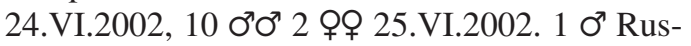
sia, S-Buryatia, $51^{\circ} 11-13^{\prime} \mathrm{N} 106^{\circ} 10-12^{\prime} \mathrm{E}, 700 \mathrm{~m}$, Hamar Daban Mountains, Murtoy river, Gusinoe ozero village $6 \mathrm{~km} \mathrm{NW}$, forest steppe, 19.VI.2002, K. Nupponen leg. $10^{\prime}$ Buryatia, $54^{\circ} 35^{\prime} \mathrm{N}$ $110^{\circ} 48^{\prime} \mathrm{E}$, Barguzin valley, Maisky village, 500 m, sandy yard, 02.-03.VII.1996, Jalava \& Kullberg leg. Genitalia slides: K. Nupponen prep. no. 2/03.X.2002 (O'), 4/04.X.2002 (O); B ̊̊B 703X $\left(\sigma^{7}\right)$. Four further genitalia preparations preserved in glycerol. Paratypes in the collections of T. \& K. Nupponen, Bengt A. Bengtsson, Zoological Institute, St. Petersburg and Finnish Museum of Natural History, University of Helsinki.

Diagnosis. Externally S. gorbunovi sp. n. resembles $S$. malozemovi sp. n., S. erinacella sp. n. and some other small, dark scythridids, but may be separated by more fuscous forewings. The male genitalia are close to those of $S$. malozemovi, but

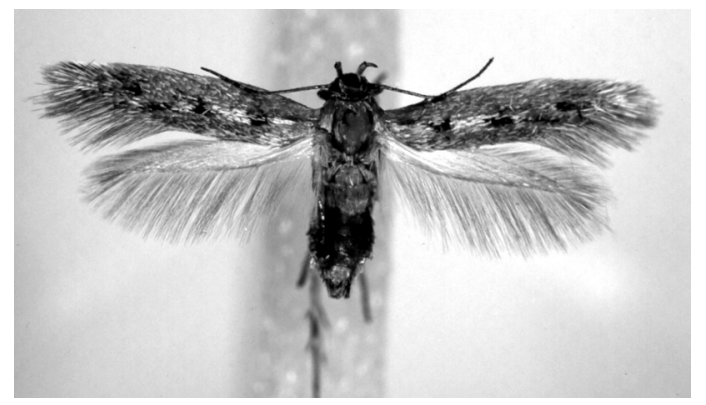

Fig. 12. Imago (holotype) of Scythris gorbunovisp. n.

differ by the valvae with longer basal shaft and convex inner margin, as well as by the shape of gnathos; in tergum VIII the posterior margin is without extensions and the sclerotized tip of lateral process is wider, shaped like a hammer. The female genitalia are close to those of S. hamatella K. \& T. Nupponen, 2001, but medioposterior incision of sternum VII is slightly deeper and the sclerotized tip of sterigma broader. See also Remarks.

Description. Wingspan 7.5-10 mm. Head, antenna, collar, tegula and thorax fuscous. Neck tuft and haustellum pale brown with a few dirty whitish scales. Labial palp: segment I white; segment II and segment III fuscous, more (segment II) or less (segment III) mixed with dirty white scales. Legs: femur dirty whitish; tibia and tarsus pale fuscous, inner surface paler; two indistinct pale rings in hindleg tibia at medial and apical spurs, former one larger. Abdomen dorsally grey, in female terminal 2/5 ochreous; ventrally dirty white. Forewing fuscous; disconnected white streak in fold from base to cell end, cut by three moderately indistinct black spots at $0.2,0.5$ and 0.75; such black spot present also at cell end; white scales exist sparsely at dorsal side of basal area and at apex. Hindwing pale fuscous, apically darker, paler than forewing.

Male genitalia (Figs. 13-14). Uncus more or less reduced, remaining portion strongly sclerotized, tip pointed. Gnathos asymmetrical, lateral margin strongly sclerotized. Tegumen extended left-posteriorly. Aedeagus thick and short, terminally bent and tapered. Valvae basally fused, subbasally with stout narrow shaft; apical 4/5 spatular, elongate, setose; inner and outer margin slightly convex, apex rounded. Sternum VIII subrectangular. Tergum VIII subtrapezoid, ante- 


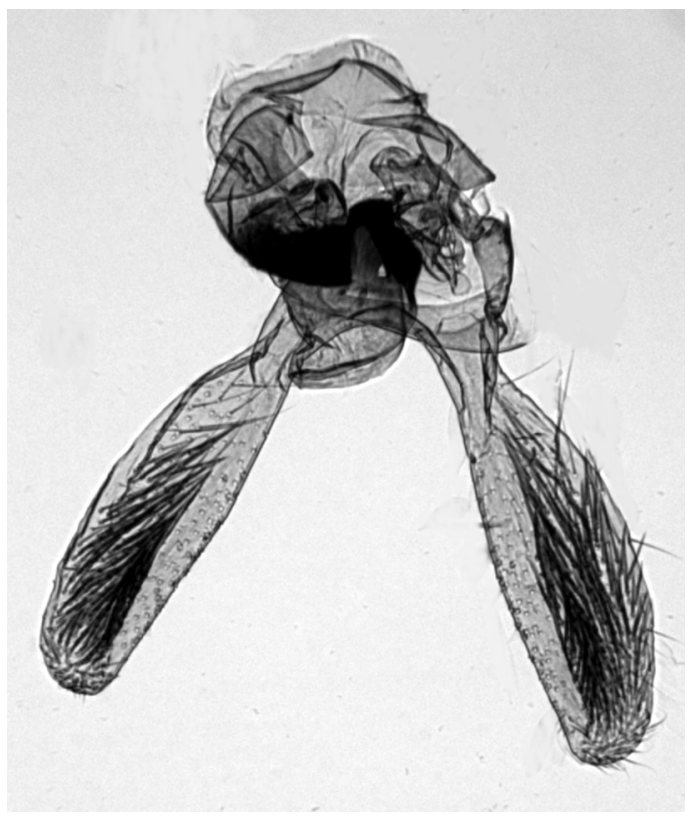

Fig. 13. Male genitalia of Scythris gorbunovi sp. n. (paratype).

rior margin concave; one lateral process reduced, another one hammer-like, distal extension of which strongly sclerotized.

Female genitalia (Fig. 15). Sterigma triangular, anterior margin widely incised; posterior part strongly sclerotized, triangular. Sternum VII subrectangular; posterior margin, medially weakly incised without sclerotization. Apophyses anteriores 0.4 length of apophyses posteriores.

Bionomy. The specimens were collected in late June. The habitat was a sandy steppe, and the taxon occurred sympatrically with $S$. malozemovi sp. n. The biology is unknown.

Distribution. Russia (S Buryatia).

Etymology. I dedicate this species to my friend Mr. Pavel Gorbunov, a Russian lepidopterologist.

Remarks. S. gorbunovi sp. n. belongs to a group of closely related small, dark species having very similar genitalia structure. In the male genitalia the following features are characteristic: basally fused, more or less spatular valvae, tegumen posteriorly extended to the left, strongly sclerotized asymmetrical gnathos, and usually tergum VIII with a lateral arm being apically sclerotized. In the female genitalia a triangular sterigma with sclerotized tip and characters in the posterior margin of sternum VII being elongate

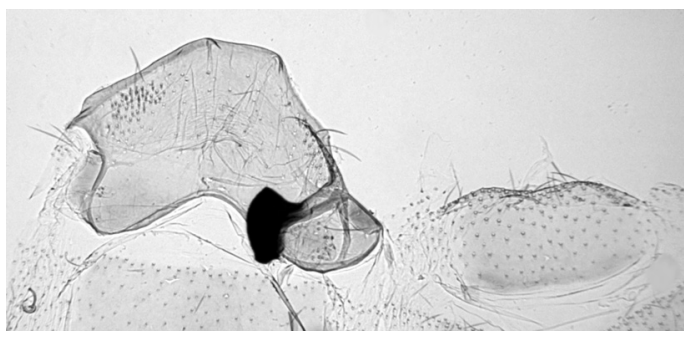

Fig. 14. Tergum VIII (left) and sternum VIII (right) of Scythris gorbunovi sp. n. (paratype).

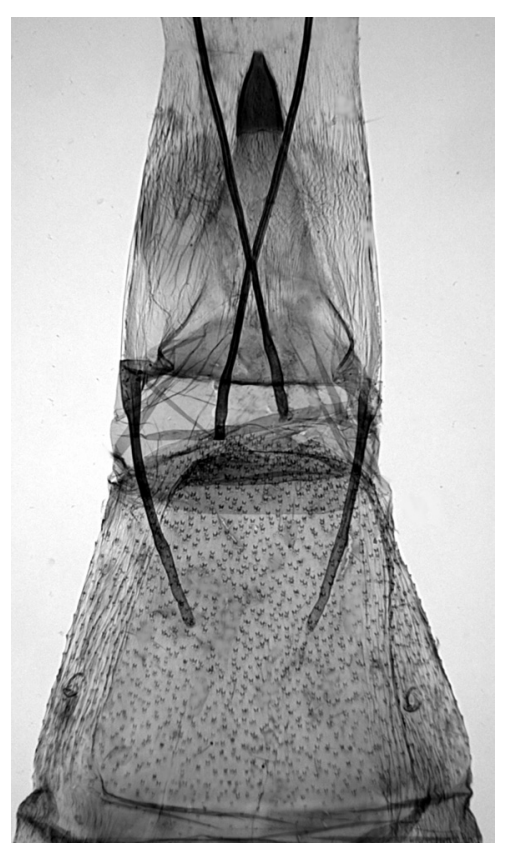

Fig. 15. Female genitalia of Scythris gorbunovisp. n. (paratype).

with medioposterior incision, often furnished with sclerotization at 'bottom' of incision, exhibit specific traits. All of the species belonging to this group were described recently: S. albisaxella K. \& T. Nupponen, 2000, S. arkaimensis Bengtsson, 2000, S. erinacella sp. n., S. cervella K. \& T. Nupponen, 2001, S. hamatella K. \& T. Nupponen, 2001, S. gorbunovi sp. n., S. kullbergi Bengtsson, 1997, S. lagomorphella Junnilainen, 2002, S. malozemovi sp. n., S. sinevi sp. n., S. terekholensis Bengtsson, 1997 and one still undescribed taxon from Turkey (Bengtsson in litt.). This complex of species might be assigned to the heterogeneous laminella-group. 


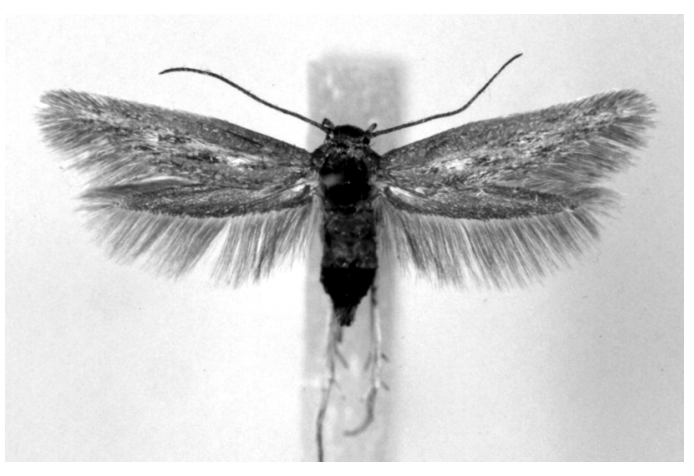

Fig. 16. Imago (holotype) of Scythris hamardabanica sp. $n$.

\section{Scythris hamardabanica sp. $\mathbf{n}$.}

Type material. Holotype: $0^{7}$ (Fig. 16): Russia, SBuryatia, 51 ${ }^{\circ} 11-13^{\prime} \mathrm{N} 106^{\circ} 10-12^{\prime} \mathrm{E}, 700 \mathrm{~m}$, Hamar Daban Mountains, Murtoy river, Gusinoe ozero village $6 \mathrm{~km} \mathrm{NW}$, forest steppe, 22.VI.2002, K. Nupponen leg. In coll. T. \& K.

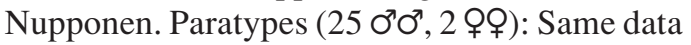
as holotype, except for dates: $30^{7} \sigma^{7} 1$ ㅇ

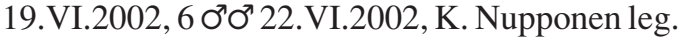
$60^{7} 0^{\prime}$ Russia, S-Buryatia, $51^{\circ} 09^{\prime} \mathrm{N} 106^{\circ} 16^{\prime} \mathrm{E}$, $550 \mathrm{~m}$, lake Gusinoe ozero, steppe, 23.VI.2002, K. Nupponen leg. Russia, S-Buryatia, 50 58$59^{\prime} \mathrm{N} 106^{\circ} 38-40^{\prime} \mathrm{E}, 550-600 \mathrm{~m}$, Chikoy valley, Novoselenginsk village $10 \mathrm{~km} \mathrm{~S}$, sand dunes/ sandy steppe, $50^{7} 0^{\prime \prime} 1$ ○ 24.VI.2002, K. Nupponen leg. $10^{\top}$ Russia, S-Buryatia, $51^{\circ} 28^{\prime} \mathrm{N}$ $106^{\circ} 33^{\prime} \mathrm{E}, 600 \mathrm{~m}$, lake Solyonoye, salt marsh/ steppe, 26.VI.2002, K. Nupponen leg. Russia, S-Buryatia, 51 $37^{\prime} \mathrm{N} 106^{\circ} 46^{\prime} \mathrm{E}, 600 \mathrm{~m}$, Hamar Daban Mountains, bolshoi Sanzheevka river, Kharamsha village $2 \mathrm{~km} \mathrm{~W}$, forest steppe, $10^{7}$ 27.VI.2002, 3 O' 28.VI.2002, K. Nupponen leg. Genitalia slides: K. Nupponen prep. no. 4/ 03.X.2002 (O'), 2/07.X.2002 (O). In coll. T. \& K. Nupponen, Bengt Å. Bengtsson and Zoological Institute, St. Petersburg.

Diagnosis. Externally S. hamardabanica sp. n. resembles $S$. potatorella sp. n., but differs from that by more fuscous forewings without distinct black streaks. Worn specimens may be confused with many dark scythridids, for example $S$. erinacella sp. n. A good diagnostic character for hamardabanica is a golden hue of the dorsal side of abdomen, appearing in both sexes. The combi-

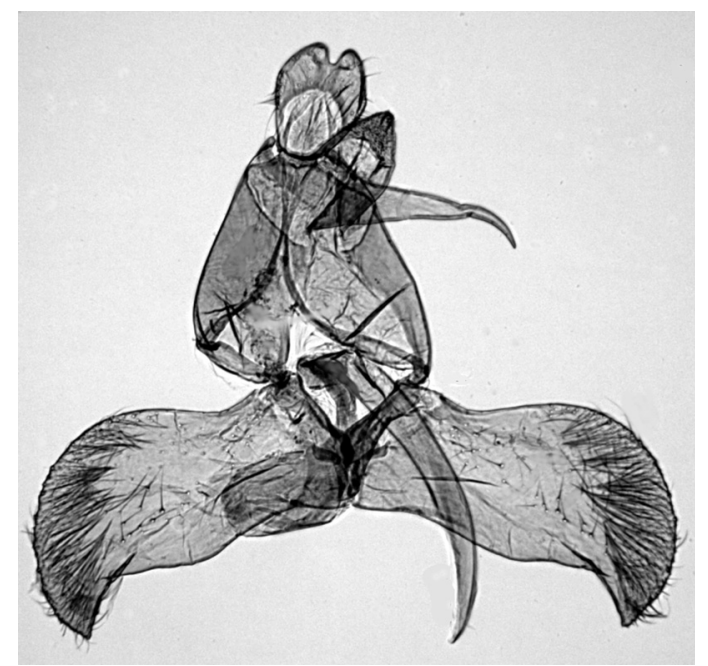

Fig. 17. Male genitalia of Scythris hamardabanica sp. n. (paratype).

nation of characters in the male genitalia (shape of uncus and valvae, a long gnathos with furrowed basal plate) indicate a relationship to $S$. elenae K. Nupponen, 2000, but valva of hamardabanica is broader and posterior margin of sternum VIII is incised. In the female genitalia, the shape of sterigma and an oval structure in sternum VII are characteristic.

Description. Wingspan 10-11.5 mm. Head, antenna and thorax dark brown. Collar and tegula brown with scattered whitish scales. Neck tuft pale ocreous. Labial palp: segment I, basal part of segment II and upper surface greyish white, otherwise dark brown. Haustellum brown mixed with pale scales. Forelegs and midlegs pale brown; hindlegs pale ochreous, tarsus darker. Abdomen dorsally fuscous, in most specimens with golden hue; ventrally dirty whitish. Forewing brownish with many short, indistinct, black longitudinal streaks, more frequently in dorsal and apical area; whole wing with scattered white scales being more numerous at black streaks and more or less sparse elsewhere. Hindwing dark fuscous.

Male genitalia (Figs. 17-18). Uncus roundish, distally incised. Gnathos base a subtriangular, furrowed plate; distal part long, tapered, terminal $1 / 5$ bent, tip pointed. Aedeagus long and slender, bent, pointed. Valva very broad, subapically broader than near base; apical 1/3 setose, bent 


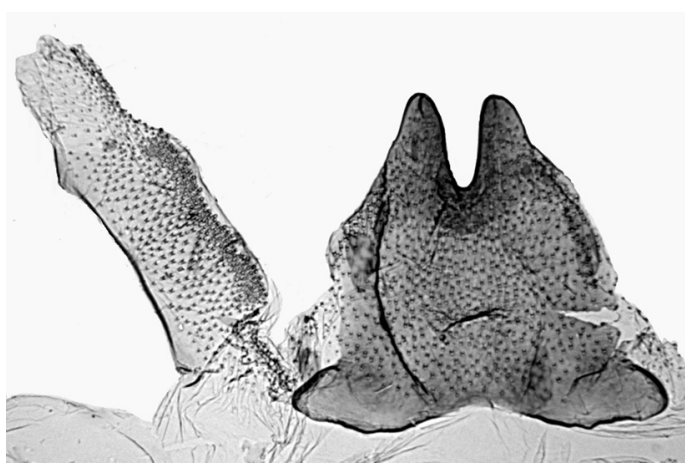

Fig. 18. Tergum VIII (left) and sternum VIII (right) of Scythris hamardabanica sp. n. (paratype).

inwards and strongly tapered, tip pointed. Sternum VIII subtriangular; posterior margin deeply incised; anterior margin slightly concave, anterior corners extended outwards. Tergum VIII rectangular, moderately membranous.

Female genitalia (Fig. 19). Sterigma stout, Ushaped, shanks extended posterolaterally. Ostium well marked, situated at anterior margin of sterigma. Sternum VII rectangular; posterior margin medially concave and with sclerotized oval structure. Apophyses anteriores 0.6 length of apophyses posteriores.

Bionomy. The specimens were collected in late June. The species occurs in dry steppe habitats. The biology is unknown.

Distribution. Russia (S Buryatia).

Etymology. The name of the species refers to its geographical origin, foothills of the Hamar Daban Mountains.

Remarks. S. hamardabanica sp. n. is a close relative to S. elenae K. Nupponen, 2000 and belongs obviously to a specific species-group (see K. Nupponen et. al. 2000). However, both taxa share features of the closely related knochella and cicadella species-groups and possibly these three groups will be fused in the future.

\section{Scythris hamatella K. \& T. Nupponen, 2001}

Russia, SW-Buryatia, $51^{\circ} 47-48^{\prime} \mathrm{N} 100^{\circ} 52-55^{\prime} \mathrm{E}$, East Sayan Mountains, $1500 \mathrm{~m}$, Mondy village $2 \mathrm{~km}$ WNW, steppe, 20 O'ర $0^{7} 13$. VI.2002, K. Nupponen leg.

Distribution. Russia (Altai).

Remarks. Previously known only from the type locality. New to the Baikal region.

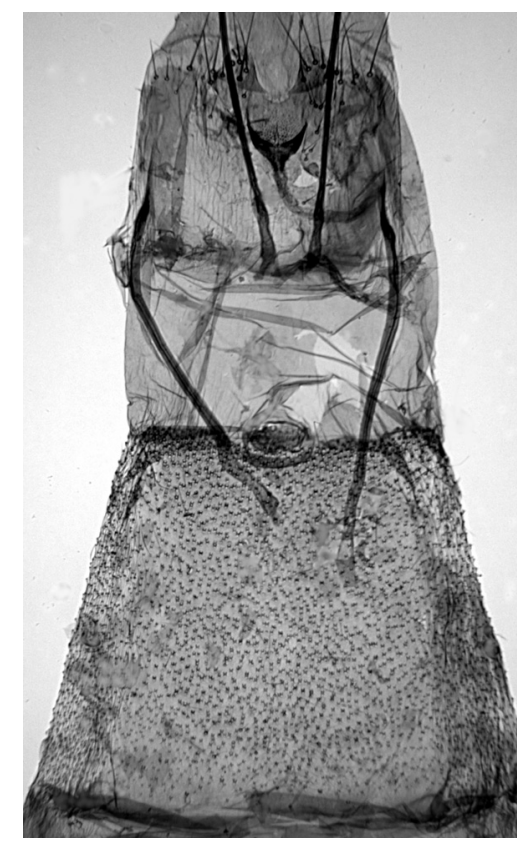

Fig. 19. Female genitalia of Scythris hamardabanica sp. n. (paratype).

\section{Scythris karinupponeni Bengtsson, 2000}

Russia, S-Buryatia, $51^{\circ} 37^{\prime} \mathrm{N} 106^{\circ} 46^{\prime} \mathrm{E}, 600 \mathrm{~m}$, Hamar Daban Mountains, bolshoi Sanzheevka river, Kharamsha village $2 \mathrm{~km} \mathrm{~W}$, forest steppe, 4 ơ $0^{7} 1$ ㅇ 27.VI.2002, K. Nupponen leg.

Distribution. Russia (S Ural, Altai, Transbaikalia, Magadan region, Primoriye).

Remarks. See Remarks of S. mikkolai below.

\section{Scythris lativalvella Sinev, 2001}

Russia, S-Buryatia, $51^{\circ} 11-13^{`} \mathrm{~N} 106^{\circ} 10-12^{`} \mathrm{E}, 700 \mathrm{~m}$, Hamar Daban Mountains, Murtoy river, Gusinoe ozero village $6 \mathrm{~km} \mathrm{NW}$, forest steppe, 2 O $^{7} \mathrm{O}^{7} 19 . \mathrm{VI} .2002,10^{7}$ 22.VI.2002, K. Nupponen leg.

Distribution. Russia (Primoriye).

Remarks. These records extend the known distribution range of S. lativalvella $2000 \mathrm{~km}$ to the west. New to the Baikal region.

\section{Scythris macrourella Sinev, 2001}

Russia, SW-Buryatia, $51^{\circ} 47-48^{\prime} \mathrm{N} 100^{\circ} 55-58^{\prime} \mathrm{E}$, East Sayan Mountains, $1450 \mathrm{~m}$, Mondy village $2 \mathrm{~km}$ E, forest steppe, 3 ơ $0^{7} 1$ ㅇ 13.VI.2002, K. Nupponen leg. 


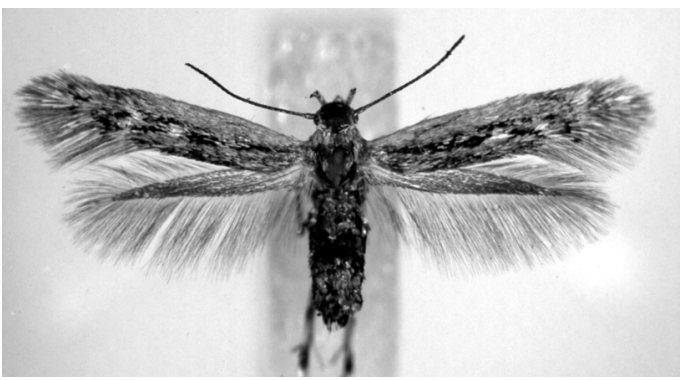

Fig. 20. Imago (holotype) of Scythris malozemovi sp. n.

Russia, SW-Buryatia, East Sayan Mountains, 900 m, Halagun river, Turan village $8 \mathrm{~km} \mathrm{~W}$, mixed forest, 4 రొర $^{7} 2$ 우 16.VI.2002, K. Nupponen leg.

Russia, S-Buryatia, $51^{\circ} 11-13^{`} \mathrm{~N} 106^{\circ} 10-12^{`} \mathrm{E}, 700 \mathrm{~m}$, Hamar Daban Mountains, Murtoy river, Gusinoe ozero vil-

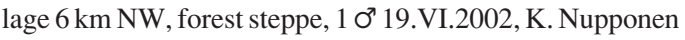
leg.

Distribution. Russia (Primoriye, Sahalin, Kamtsatka, Amur, Jakutia, Baikal region, Altai, Tuva), Mongolia, North Korea.

\section{Scythris malozemovi sp. $\mathrm{n}$.}

Type material. Holotype: O' (Fig. 20): Russia, SBuryatia, 5058-59’ N 106³8-40`E, 550-600 m, Chikoy valley, Novoselenginsk village $10 \mathrm{~km} \mathrm{~S}$, sand dunes/sandy steppe, 24.VI.2002, K. Nupponen leg. In coll. T. \& K. Nupponen. Paratypes (37 $0^{7} 0^{7}, 15$ 우): Same data as holotype, except for dates: 2 Ơ $^{7} 2$ 우 23.VI.2002, 24 O $^{7} 0^{7}$ 11 우우 24.VI.2002, 10 0'ర 2 우우 25.VI.2002. $10^{7}$ Russia, Tuva, Saryg-Sep, 17.VI.1976, Rezhnik leg. Genitalia slides: K. Nupponen prep. no. 5/ 03.X.2002 (O'), 5/04.X.2002 (O). Two further genitalia preparations preserved in glycerol. Paratypes in the collections of T. \& K. Nupponen, Bengt Å. Bengtsson, Zoological Institute, St. Petersburg and Finnish Museum of Natural History, University of Helsinki.

Diagnosis. Externally S. malozemovi sp. n. may be mixed with several small scythridids, for example $S$. erinacella $\mathrm{sp}$. n. and $S$. gorbunovi sp. n.. The male genitalia are similar to those of $S$. gorbunovi, but differ in certain details: the valva is shorter with straight inner margin and the shape of gnathos is different; in tergum VIII there are two digitate processes at posterior margin and the sclerotized tip of lateral process is bifurcate. The

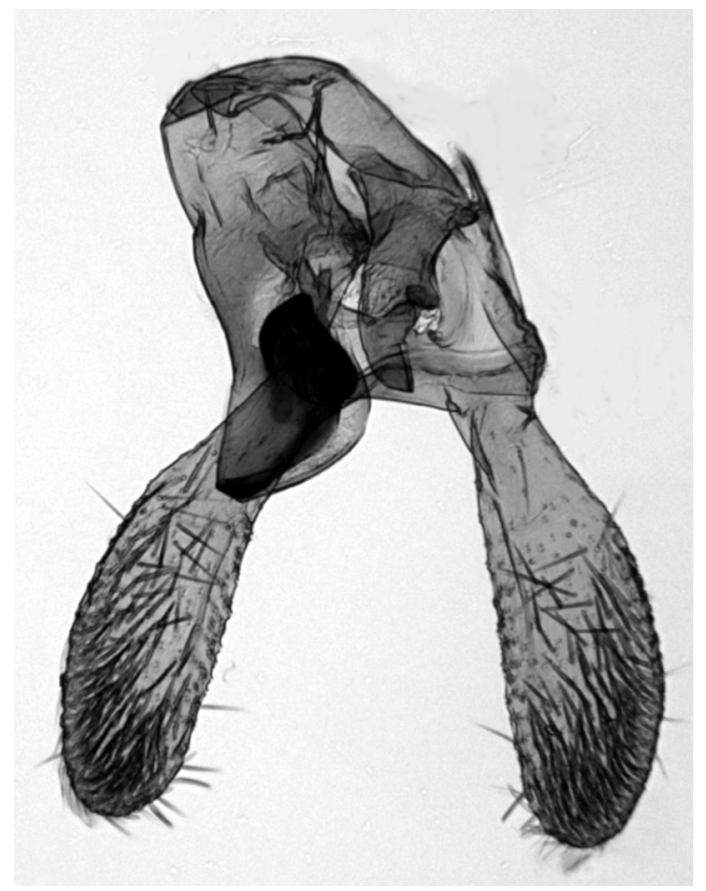

Fig. 21. Male genitalia of Scythris malozemovi sp. $\mathrm{n}$. (paratype).

female genitalia are close to those of $S$. sinevi sp. $\mathrm{n}$., but sclerotization at the tip of sterigma is less extended and medioposterior incision of sternum VII shows a narrow sclerotized belt at 'bottom'. See also Remarks of $S$. gorbunovi sp. n. above.

Description. Wingspan 9-10.5 mm. Head, antenna and thorax brown with a few paler scales. Collar and tegula pale brown. Neck tuft whitish. Labial palp: segment I and II whitish, segment III brown with a few pale scales. Haustellum brown mixed with paler scales. Forelegs and midlegs dark brown with scattered pale scales. Hindlegs whitish ochreous with following moderately distinct dark brown rings: narrow ring at apex of femur; two large rings in tibia at 0.2 and 0.8 ; large rings in tarsus at base, 0.5 and at apex. Abdomen: dorsal side fuscous in male; in female basal $1 / 3$ fuscous, medial half pale ochreous, terminal 1/6 dark brown with pale ochreous lateral sides; ventrally whitish ochreous. Forewing pale brown; indistinct white streak in fold from base to $3 / 4$, cut by three small, black spots at 0.2, 0.4 and 0.6 ; black scales are more or less frequently present also near dorsal margin and at apex; a few white scales at apex. Hindwing fuscous. 


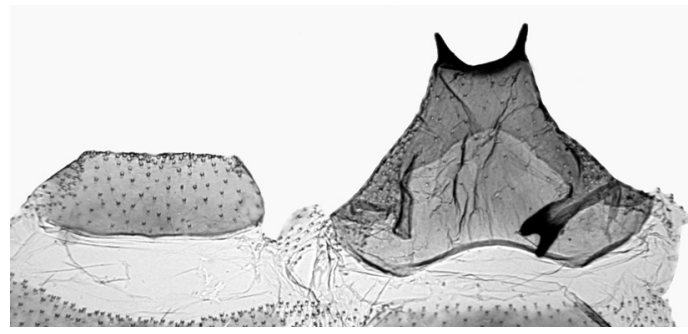

Fig. 22. Tergum VIII (right) and sternum VIII (left) of Scythris malozemovi sp. n. (paratype).

Male genitalia (Figs. 21-22). Uncus reduced. Gnathos asymmetrical; lateral extension strongly sclerotized, sclerotized belt extended up to tip. Tegumen extended left-posteriorly. Aedeagus short and thick, basally extended, tip bent and tapered. Valvae basally fused, spatular, elongate; inner margin straight, outer convex, apex rounded. Sternum VIII subrectangular. Tergum VIII subtriangular; posterior margin sclerotized with two thin digitate processes; anterior margin slightly concave; one lateral process reduced, another one robust, distally bifurcate and sclerotized.

Female genitalia (Fig. 23). Sterigma triangular, anterior margin concave; posterior portion strongly sclerotized, trapezoid, tip blunt. Sternum VII subrectangular; posterior margin widely incised; weak sclerotization at 'bottom' of incision. Apophyses anteriores 0.3 length of apophyses posteriores.

Bionomy. The specimens were collected in late June. The species was common in sandy steppe with Artemisia spp. and Thymus as dominant plants. The biology is unknown.

Distribution. Russia (S Buryatia, Tuva).

Etymology. I dedicate this species to my friend Mr. Alexander Malozemov, a Russian entomologist.

Remarks. S. malozemovi sp. n. belongs to the complex of species treated in Remarks of $S$. gorbunovi sp. n. (see above).

\section{Scythris mikkolai Sinev, 1993}

Russia, S-Buryatia, $51^{\circ} 11-13^{`} \mathrm{~N} 106^{\circ} 10-12^{`} \mathrm{E}, 700 \mathrm{~m}$, Hamar Daban Mountains, Murtoy river, Gusinoe ozero village $6 \mathrm{~km} \mathrm{NW}$, forest steppe, 3 Ơ $^{7} 1$ ㅇ 19.VI.2002, 2 O’ర $^{7}$ 22.VI.2002, K. Nupponen leg.

Russia, S-Buryatia, $50^{\circ} 58-59^{\prime} \mathrm{N} 106^{\circ} 38-40^{\prime} \mathrm{E}, 550$ $600 \mathrm{~m}$, Chikoy valley, Novoselenginsk village $10 \mathrm{~km} \mathrm{~S}$,

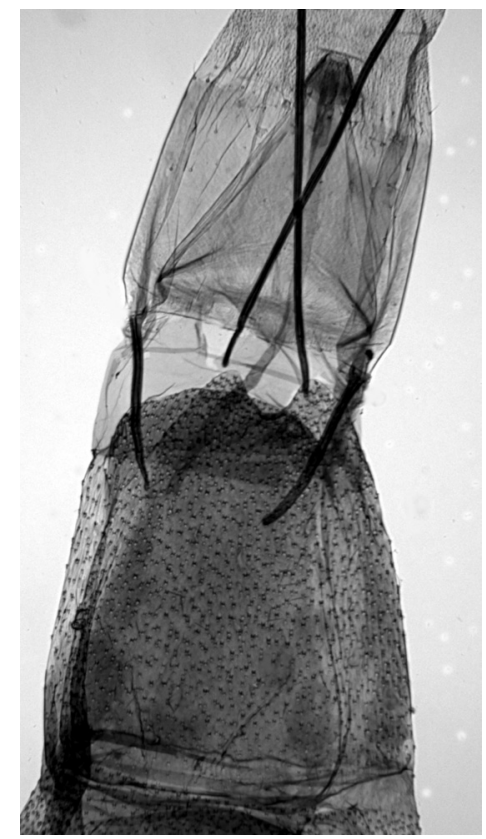

Fig. 23. Female genitalia of Scythris malozemovi sp. n. (paratype).

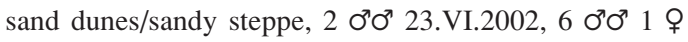

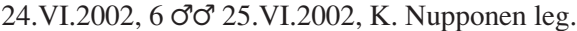

Russia, S-Buryatia, $51^{\circ} 28^{\prime} \mathrm{N} 106^{\circ} 33^{\prime} \mathrm{E}, 600 \mathrm{~m}$, lake Solyonoye, salt marsh/steppe, 2 ơ $0^{7}$ 26.VI.2002, K. Nupponen leg.

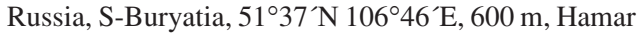
Daban Mountains, bolshoi Sanzheevka river, Kharamsha village $2 \mathrm{~km} \mathrm{~W}$, forest steppe, 11 O’ర $^{\top} 11$ 우 27.VI.2002, 1 ơ 2 웅 28.VI.2002, K. Nupponen leg.

Russia, S-Buryatia, Ulan-Ude $10 \mathrm{~km} \mathrm{~W}$, near Gurulba village, meadow/steppe, 700 m, 3 ơ రో 2 우 29.VI.2002, K. Nupponen leg.

Distribution. Russia (Primoriye, S Siberia, S Ural, Samara region).

Remarks. The species is abundant in various kinds of steppe habitats. The female of S. mikkolai is much smaller in size (wingspan 9-11.5 mm) than the male (wingspan 12.5-14.5 mm) and probably it does not fly much. The whitish streak in fold of the forewing is varying from distinct to almost invisible and the moth is easily confused with S. karinupponeni Bengtsson, 2000. The female genitalia of $S$. mikkolai are illustrated for the first time (Fig. 24); they are very close to those of S. karinupponeni (Fig. 25), but can be separated from those by the broader, triangular sterigma and posterior margin of sternum VII being straight with only a shallow medial incision, while 


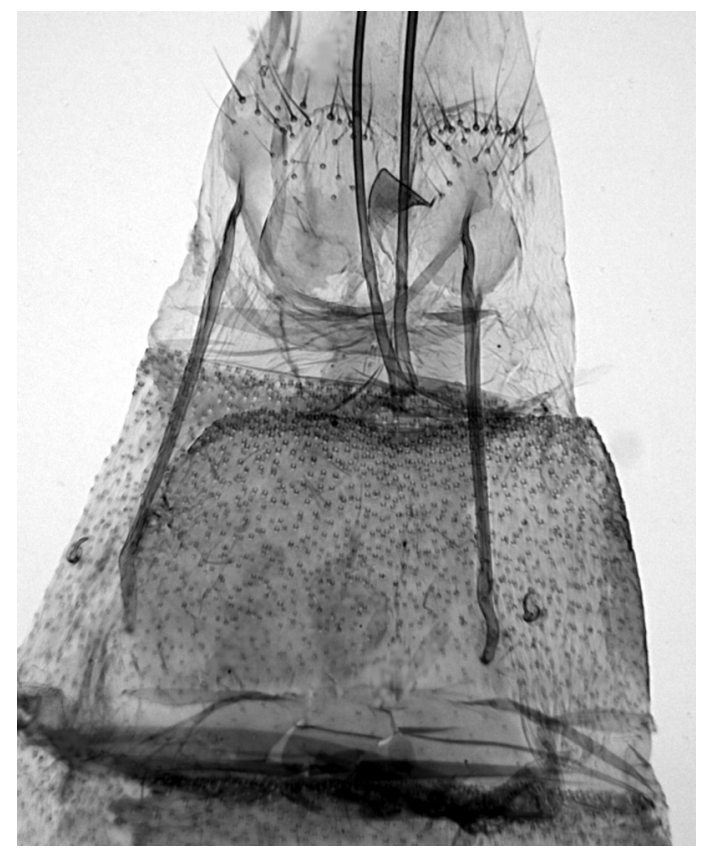

Fig. 24. Female genitalia of Scythris mikkolai Sinev, 1993.

in S. karinupponeni the sterigma is posteriorly elongate with very sharp tip and the whole posterior margin of sternum VII is incurved. In the original description of S. lativalvella (Sinev 2001; see also Sinev 2001a) the drawing of the female genitalia is very similar to that of S. mikkolai and possibly represents the latter species. However, the short description does not allow this assumption to be confirmed.

\section{Scythris minorella Sinev, 2001}

Russia, S-Buryatia, 50 58-59`N 106³8-40`E, 550-600 m, Chikoy valley, Novoselenginsk village $10 \mathrm{~km} \mathrm{~S}$, sand dunes/ sandy steppe, 6 Oro $^{7} 4$ 우 24.VI.2002, K. Nupponen leg.

Russia, S-Buryatia, $51^{\circ} 37^{\prime} \mathrm{N} 106^{\circ} 46^{`} \mathrm{E}, 600 \mathrm{~m}$, Hamar

Daban Mountains, bolshoi Sanzheevka river, Kharamsha village $2 \mathrm{~km} \mathrm{~W}$, forest steppe, 10 ơ $^{7} 6$ 우 27.VI.2002, 6 0"Oొ 6 우 28.VI.2002, K. Nupponen leg.

Russia, S-Buryatia, Ulan-Ude $10 \mathrm{~km} \mathrm{W,} \mathrm{near} \mathrm{Gurulba}$ village, meadow/steppe, $700 \mathrm{~m}, 1$ ᄋ 29.VI.2002, K. Nupponen leg.

Distribution. Russia (Magadan region, Tshukotka, Altai), Mongolia.

Remarks. New to the Baikal region.

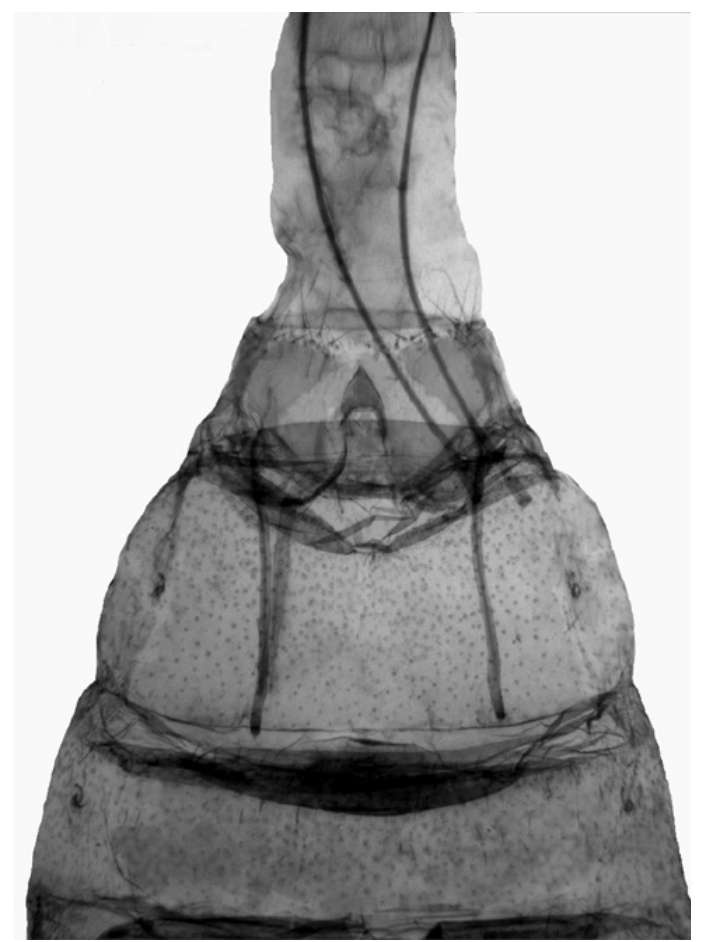

Fig. 25. Female genitalia of Scythris karinupponeni Bengtsson, 2000.

\section{Scythris ninae sp. n.}

Type material. Holotype: $\sigma^{7}$ (Fig. 26): Russia, SBuryatia, 5058-59`N 106³8-40’E, 550-600 m, Chikoy valley, Novoselenginsk village $10 \mathrm{~km} \mathrm{~S}$, sand dunes/sandy steppe, 24.VI.2002, K. Nupponen leg. In coll. T. \& K. Nupponen. Paratype (1 $\left.\sigma^{7}\right)$ : Same data as holotype. Genitalia slide: K. Nupponen prep. no. 3/04.X.2002. In coll. T. \& K. Nupponen.

Diagnosis. Externally S. ninae sp. n. may be confused with several other dark scythridids, for example S. eversmanni K. \& T. Nupponen, 2000 and S. sublaminella K.\& T. Nupponen, 2000. The male genitalia of $S$. ninae indicate a close relationship to $S$. eversmanni (see Remarks) but differ from that by the rectangular terminal process and thin posterolateral processes of tergum VIII, as well as by the shape of distal part of sternum VIII and uncus.

Description. Wingspan 10-10.5 mm. Head, antenna and thorax dark brown. Collar brown, 


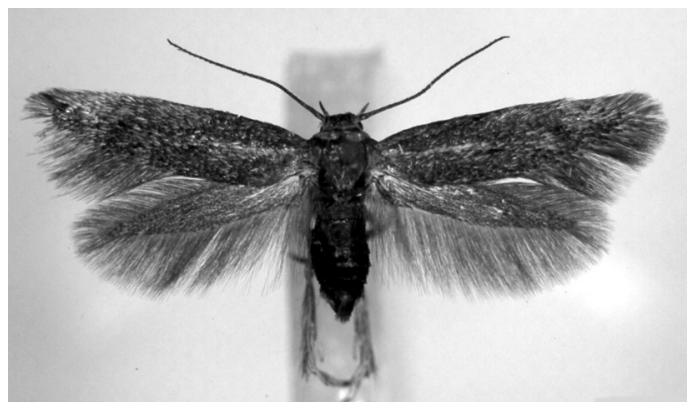

Fig. 26. Imago (holotype) of Scythris ninae sp. n.

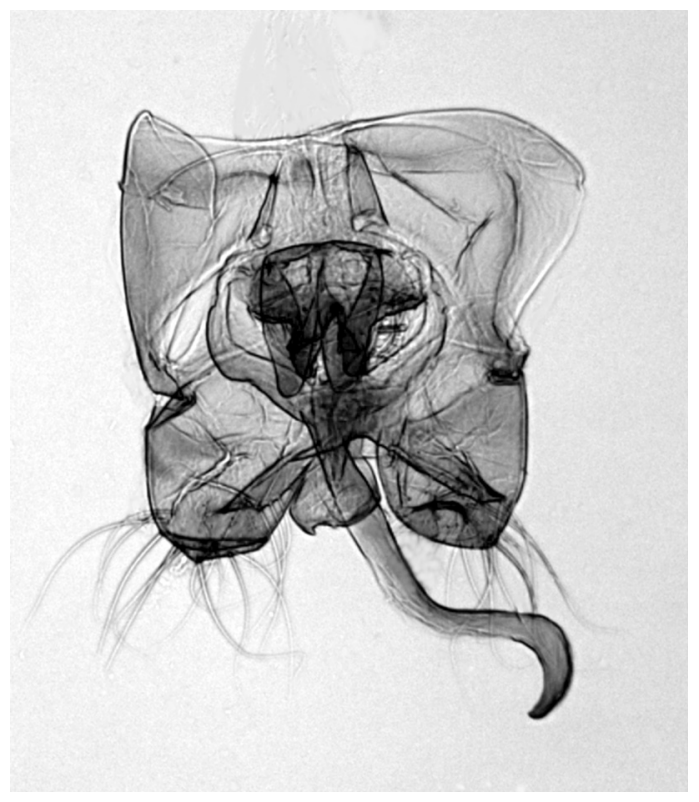

Fig. 27. Male genitalia of Scythris ninae sp. n. (paratype).

neck tuft and tegula pale brown. Haustellum basally dark brown, distal half whitish grey. Labial palp: segment I pale brown; upper surface and basal part of segment II pale brown, otherwise dark brown. Forelegs and midlegs: femur pale brown, tibia and tarsus dark brown mixed with paler scales. Hindlegs pale brown, tibia with long hairscales. Abdomen dorsally dark brown, slightly glossy; ventral side basally black, distal 2/3 pale brown, terminal scales whitish. Forewing dark brown; in fold beige scales forming streak from base to tornus; such pale scales occur very sparsely at basal area but frequently at apical half; small,

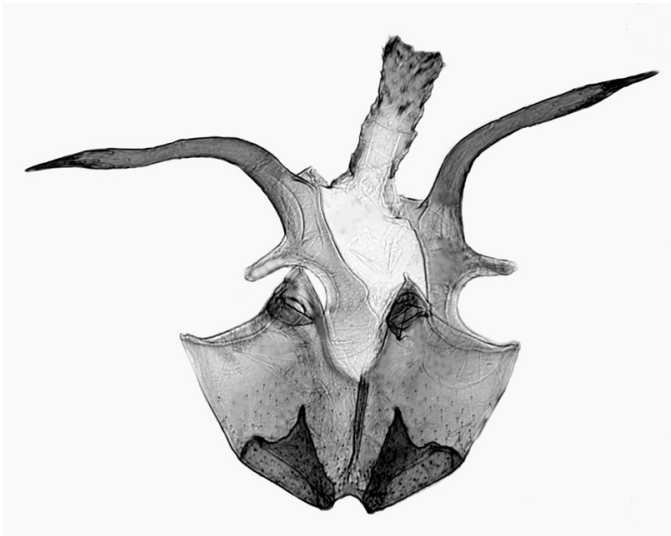

Fig. 28. Tergum VIII (up) and sternum VIII (down) of Scythris ninae sp. n. (paratype).

indistinct black spot at cell end. Hindwing fuscous.

Male genitalia (Figs. 27-28). Uncus elongate, distally deeply incised; basal part laterally extended and terminally with two thick digitate processes. Gnathos base a pentagonal band; posterior part long, bent at $2 / 3$, tip hooked. Tegumen extended posterolaterally. Aedeagus straight and thick, basally enlarged and roundish. Valva setose, short, cup-shaped. Sternum VIII subpentagonal; posterior margin medially with small U-shaped incision; posterior corners subtriangularly extended with pointed tip; anterior margin with deep, U-shaped incision surrounded by two triangular extensions having semicircular bulge medially. Tergum VIII subrectangular with following extensions: terminal process rectangular, straight, posterior margin slightly concave; posterolateral processes moderately thin, curved outwards at 1/4, apically tapered, tip pointed; laterally near anterior corners short, thick, digitate processes.

Female genitalia. Unknown.

Bionomy. The specimens were collected in late June. The habitat was a sandy steppe. The biology is unknown.

Distribution. Russia (S Buryatia). Only known from the type locality.

Etymology. I dedicate this species to my daughter Nina.

Remarks. S. ninae sp. n. is a close relative to S. eversmanni, K. \& T. Nupponen, 2000, a species recorded from the foothills of the southern 


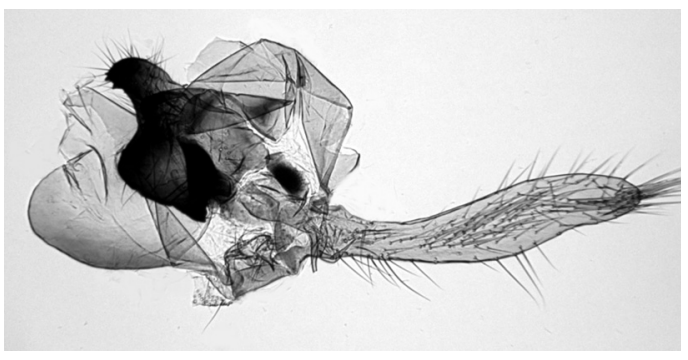

Fig. 29. Male genitalia of Scythris penicillata Chrétien, 1900 (S. Buryatia).

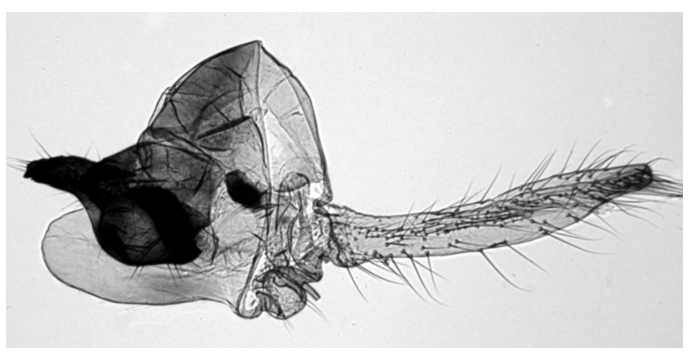

Fig. 30. Male genitalia of Scythris penicillata Chrétien, 1900 (Estonia, Saaremaa).

Ural Mountains. To date these two species are the only ones known belonging to this species-group (see Nupponen et al. 2000).

\section{Scythris nitidella Bengtsson \& Liška, 1996}

Russia, S-Buryatia, $51^{\circ} 11-13^{\prime} \mathrm{N} 106^{\circ} 10-12^{\prime} \mathrm{E}, 700 \mathrm{~m}$, Hamar Daban Mountains, Murtoy river, Gusinoe ozero village $6 \mathrm{~km} \mathrm{NW}$, forest steppe, $1 \mathrm{O}^{\mathrm{r}} 19$.VI.2002, K. Nupponen leg.

Distribution. Russia (Tuva, Jakutia, Magadan region), Mongolia, North Korea.

Remarks. New to the Baikal region.

\section{Scythris obscurella (Scopoli, 1763)}

Russia, S-Buryatia, $51^{\circ} 11-13^{\prime} \mathrm{N} 106^{\circ} 10-12^{\prime} \mathrm{E}, 700 \mathrm{~m}$, Hamar Daban Mountains, Murtoy river, Gusinoe ozero vil-

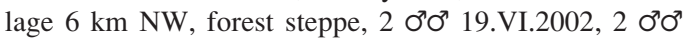

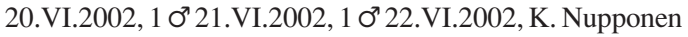
leg.

Russia, S-Buryatia, Ulan-Ude $10 \mathrm{~km} \mathrm{W,} \mathrm{near} \mathrm{Gurulba}$ village, meadow/steppe, $700 \mathrm{~m}, 2$ ơ $^{7}$ 29.VI.2002, K. Nupponen leg.

Distribution. Transpalaearctic.

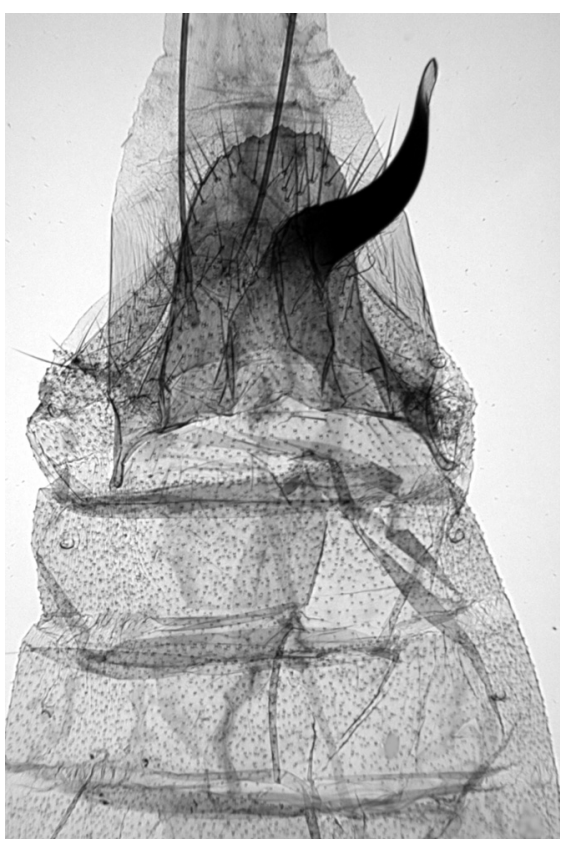

Fig. 31. Female genitalia of Scythris penicillata Chrétien, 1900 (S. Buryatia).

\section{Scythris orientella Sinev, 2001}

Russia, SW-Buryatia, $51^{\circ} 47-48^{`} \mathrm{~N} 100^{\circ} 55-58^{`} \mathrm{E}$, East Sayan Mountains, $1450 \mathrm{~m}$, Mondy village $2 \mathrm{~km} \mathrm{E}$, forest steppe, $20^{\prime} 0^{\prime \prime} 13$. VI.2002, K. Nupponen leg.

Russia, S-Buryatia, $51^{\circ} 11-13^{\prime} \mathrm{N} 106^{\circ} 10-12^{\prime} \mathrm{E}, 700 \mathrm{~m}$, Hamar Daban Mountains, Murtoy river, Gusinoe ozero village $6 \mathrm{~km} \mathrm{NW}$, forest steppe, 11 Ơర $^{7} 1$ ㅇ 19.VI.2002, 1 ㅇ 21.VI.2002, $70^{7} 0^{7} 4$ 우 22.VI.2002, K. Nupponen leg. Russia, S-Buryatia, 50 58-59`N 106³8-40`E, 550-600 m, Chikoy valley, Novoselenginsk village $10 \mathrm{~km} \mathrm{~S}$, sand dunes/ sandy steppe, 1 O’ 23.VI.2002, 1 O' 24.VI.2002, K. Nupponen leg.

Russia, S-Buryatia, $51^{\circ} 37^{\prime} \mathrm{N} 106^{\circ} 46^{\prime} \mathrm{E}, 600 \mathrm{~m}$, Hamar Daban Mountains, bolshoi Sanzheevka river, Kharamsha village $2 \mathrm{~km} \mathrm{~W}$, forest steppe, $10^{7} 2$ 우 27.VI.2002, $10^{7}$ 28.VI.2002, K. Nupponen leg.

Distribution. Russia (Primoriye, Amur, Buryatia, Krasnojarskij kraj, S Siberia), Mongolia.

\section{Scythris penicillata Chrétien, 1900}

Russia, S-Buryatia, 51 ${ }^{\circ} 37^{\prime} \mathrm{N} 106^{\circ} 46^{\prime} \mathrm{E}, 600$ m, Hamar Daban Mountains, bolshoi Sanzheevka river, Kharamsha village $2 \mathrm{~km} \mathrm{~W}$, forest steppe, 9 రౌơ 6 우 27.VI.2002, 24 ○’రా 24 우 28.VI.2002, K. Nupponen leg. Genitalia slides: K. Nupponen prep. no. 1/04.X.2002 (0"), 7/04.X.2002 (Q). Distribution. France, Estonia. 


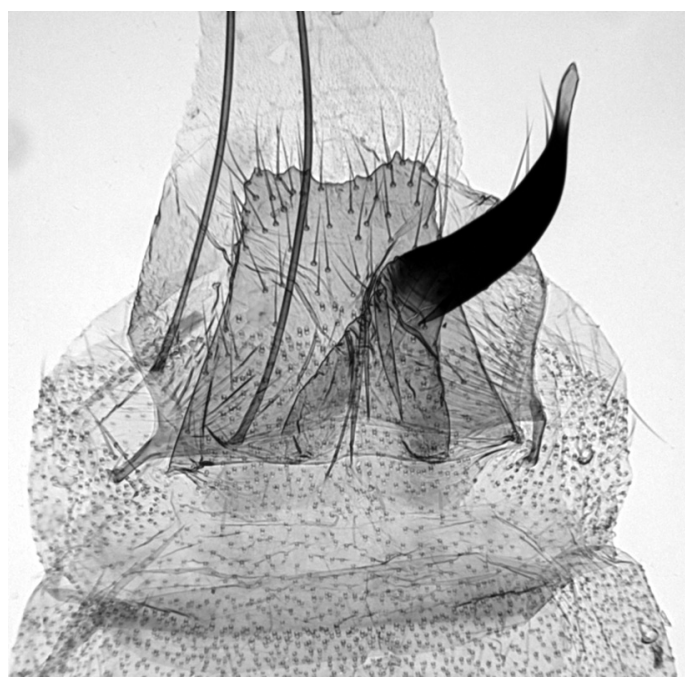

Fig. 32. Female genitalia of Scythris penicillata Chrétien, 1900 (Estonia, Saaremaa).

Remarks. All specimens were collected by sweeping on Cerastium arvense L. (P. Kulikov det.), evidently the host plant of $S$. penicillata in Buryatia. However, Chrétien (1900) reports Alsine mucronata L. as a host plant. Probably the larva feeds on several plants belonging to the family Caryophyllaceae. This surprising record extends the known distribution range of penicillata $5500 \mathrm{~km}$ to the east. New to Russia and eastern Palaearctic region.

Buryatian specimens are on average larger in size (wingspan 8.5-11 mm) than those from western Europe. Compared with Estonian specimens, there are also minor differences in the genitalia: the right valva is a little bit broader as well as lateral extension of tegumen; in gnathos the basal extension is short and thick with stronger teeth at apex, and medial part is more extended (Figs. 2930). The ventral plate of segment VIII in the female genitalia is longer with rounded posterior corners (Figs. 31-32). Although the shape of these organs is rather constant inside the populations, the differences are insufficient for separating the taxa at species level. For the moment it is considered to be a 'normal' variation between allopatric populations living far from each other. The examination of further material from new localities in Siberia may help to solve the problem.

The male genitalia are rather complex and difficult to interpret in certain details in the

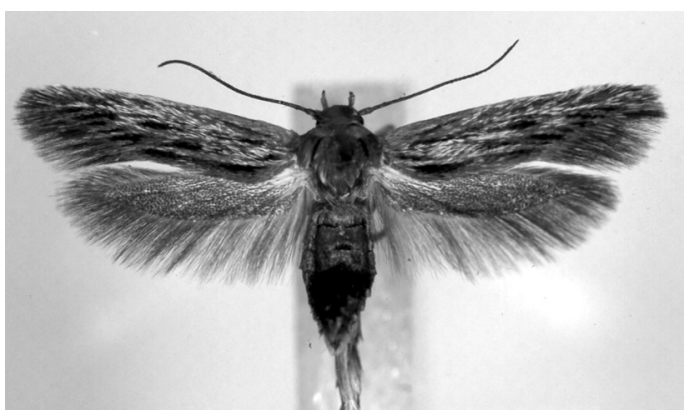

Fig. 33. Imago (holotype) of Scythris potatorella sp. n.

penicillata species-group including two taxa, $S$. penicillata and S. spinella K. \& T. Nupponen, 2001. Especially the genitalia mounted on a slide are problematic and easily lead to misunderstandings, because some details become hidden under a strongly sclerotized gnathos. The left valva of both taxa is a small protrusion that often becomes overlooked, and the large, elongate formation at left side is a lateral extension of tegumen (Figs. 29-30; c.f. K. \& T. Nupponen 2001, Bengtsson 1997a). Uncus of both taxa is reduced, although there exist some indefinite, more or less membranous formations connected to gnathos/tegumen (invisible in Figs. 29-30; c.f. K. \& T. Nupponen 2001). However, the status of the narrow, sclerotized lateral extensions of tegumen remains still unclear. The abdominal segment VIII is twisted in such a way that the sternal and tergal segments lie almost on lateral sides of the genitalia. Both sternum VIII and tergum VIII are membranous and do not include any diagnostic characters.

\section{Scythris potatorella sp. $\mathrm{n}$.}

Type material. Holotype: $0^{7}$ (Fig. 33): Russia, SBuryatia, 51 $37^{\prime} \mathrm{N} 106^{\circ} 46^{\prime} \mathrm{E}, 600 \mathrm{~m}$, Hamar Daban Mountains, bolshoi Sanzheevka river, Kharamsha village $2 \mathrm{~km} \mathrm{~W}$, forest steppe, 28.VI.2002, K. Nupponen leg. In coll. T. \& K. Nupponen. Paratypes ( $90^{7} 0^{7}, 2$ 우): Same data as holotype, except for dates: 3 O $^{7} 0^{7} 27 . V I .2002,10^{7}$ 1 ㅇ 28.VI.2002. $10^{7}$ Russia, S-Buryatia, 51 ${ }^{\circ} 11-$ $13^{`}$ N 106¹0-12`E, 700 m, Hamar Daban Mountains, Murtoy river, Gusinoe ozero village $6 \mathrm{~km}$ NW, forest steppe, 22.VI.2002, K. Nupponen leg. 


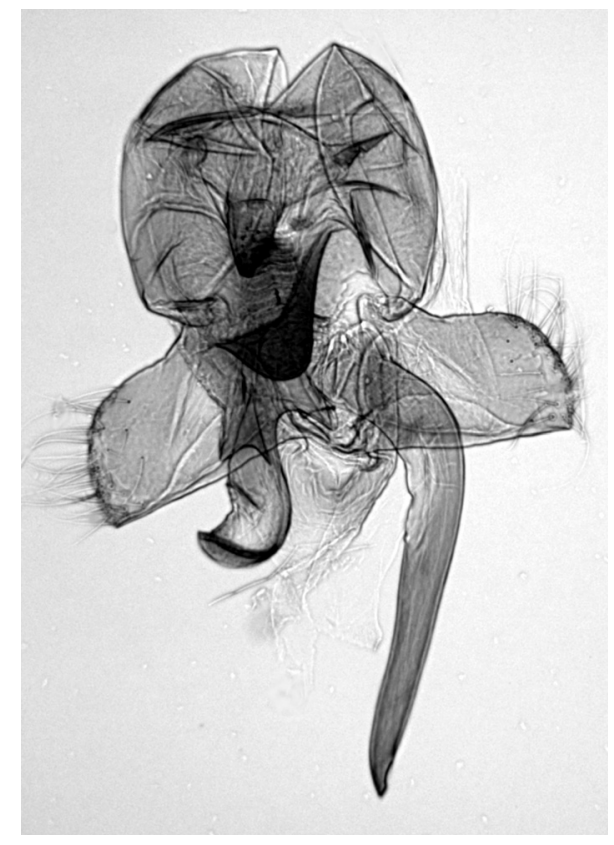

Fig. 34. Male genitalia of Scythris potatorella sp. $\mathrm{n}$. (paratype).

$40^{7} 0^{7} 1$ ㅇ Russia, S-Buryatia, $50^{\circ} 58-59^{\prime} \mathrm{N}$ 106 38-40’E, 550-600 m, Chikoy valley, Novoselenginsk village $10 \mathrm{~km} \mathrm{~S}$, sand dunes/ sandy steppe, 24.VI.2002, K. Nupponen leg. Genitalia slides: K. Nupponen prep. no. 2/04.X.2002 $\left(0^{7}\right), 6 / 04 . X .2002$ (Q). One further genitalia preparation preserved in glycerol. In coll. T. \& K. Nupponen.

Diagnosis. Externally S. potatorella sp. n. resembles S. hamardabanica sp. n., but differs from that by brown ground colour and a characteristic, distinct black streak near base at dorsal margin of the forewing. The male genitalia are easy to separate from all known scythridids by the unique shape of gnathos and short, thick valvae. In the female genitalia the square tip of sterigma and a sclerotized structure of segment VII are characteristic.

Description. Wingspan 10.5-12 mm. Head, antenna, collar, tegula, neck tuft and thorax brown, thorax with a few white scales. Haustellum creamcoloured, basally mixed with brown scales. Labial palp: segment I pale ochreous; segment II and III dark brown, basal part of segment II and upper surface mixed with whitish ochreous scales. Legs: femur cream-coloured; tarsus and tibia pale

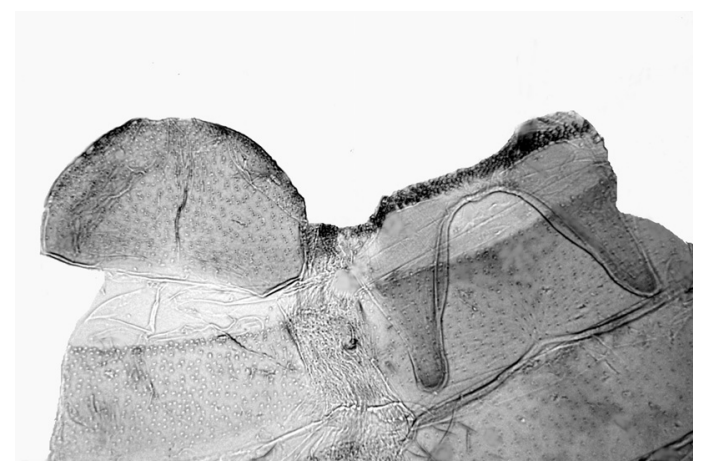

Fig. 35. Tergum VIII (right) and sternum VIII (left) of Scythris potatorella sp. n. (paratype).

brown, inner surface paler; apical 1/5 of tarsus dark brown. Abdomen dorsally fuscous; ventral side pale ochreous, in male basally greyish. Forewing brown with scattered greyish white scales; several short, thick, more or less distinct, black longitudinal streaks occur around fold and at dorsal area from base to apex, most distinct one at $1 / 10$ close to dorsal margin. Hindwing fuscous, cilia brownish at apical half of wing.

Male genitalia (Figs. 34-36). Uncus robust, subtriangular; distal process bent, tip pointed. Gnathos base wide, attached to tegumen, dorsally with elongate, furrowed, terminally pointed bulge; distal portion robust, vertically flattened, asymmetrical: at middle on both sides lateral extension of different size and subapically semicircular ridge; tip a widened, bent plate. Tegumen cup-shaped. Aedeagus long, curved $50^{\circ}$ at $1 / 5$; distal 4/5 straight, slightly tapered, tip pointed. Valva short, very broad, basal $1 / 5$ broadest; inner margin straight; outer margin strongly convex, setose; tip pointed at ventral margin. Sternum VIII semicircular. Tergum VIII square, anteriorly with deep excavation almost reaching posterior margin.

Female genitalia (Fig. 37). Sterigma triangular, basally wide; tip strongly sclerotized, square, posterior margin uneven; anterior margin widely incised. Sternum VII rectangular, posterior margin medially incised; segment VII medially furnished with sclerotized formation shaped like a champagne glass: a longish portion with straight posterior margin and an elongate anterior part connected perpendicularly to a roundish basal portion. Apophyses posteriores long and slender. 


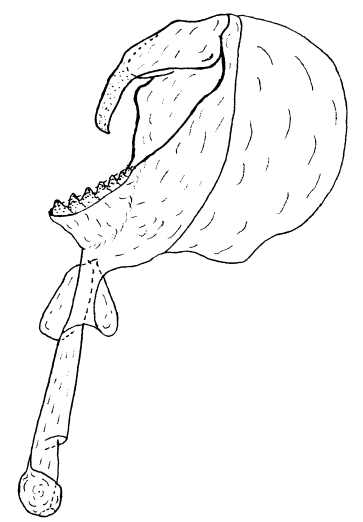

Fig. 36. Schematic drawing of the uncus-gnathoscomplex of Scythris potatorella sp. $\mathrm{n}$.

Apophyses anteriores short and bent, 1/6 length of apophyses posteriores.

Bionomy. The specimens were collected in late June. The species occurs in dry steppe habitats, preferably on rocky or gravelly spots. The biology is unknown.

Distribution. Russia (S Buryatia).

Etymology. Lat. potator $=$ drinker. The species name is connected to the sclerotized structure of segment VII in the female genitalia, giving an impression of an empty champagne glass.

Remarks. S. potatorella sp. $\mathrm{n}$. is provisionally placed in the heterogeneous laminella speciesgroup.

\section{Scythris productella (Zeller, 1839)}

Russia, S-Buryatia, Ulan-Ude $10 \mathrm{~km} \mathrm{W,} \mathrm{near} \mathrm{Gurulba} \mathrm{vil-}$

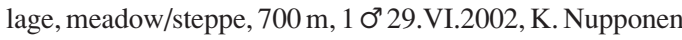
leg.

Distribution. Europe, S Ural, S Siberia, Transbaikalia.

\section{Scythris remexella K. Nupponen \& Kaitila, 2000}

Russia, S-Buryatia, 5058-59`N 106³8-40`E, 550-600 m, Chikoy valley, Novoselenginsk village $10 \mathrm{~km} \mathrm{~S}$, sand dunes/ sandy steppe, 1 Ơ 24.VI.2002, K. Nupponen leg.

Distribution. Russia (S Ural, Altai).

Remarks. This record extends the known distribution range of $S$. remexella $1400 \mathrm{~km}$ to the east. New to the Baikal region.

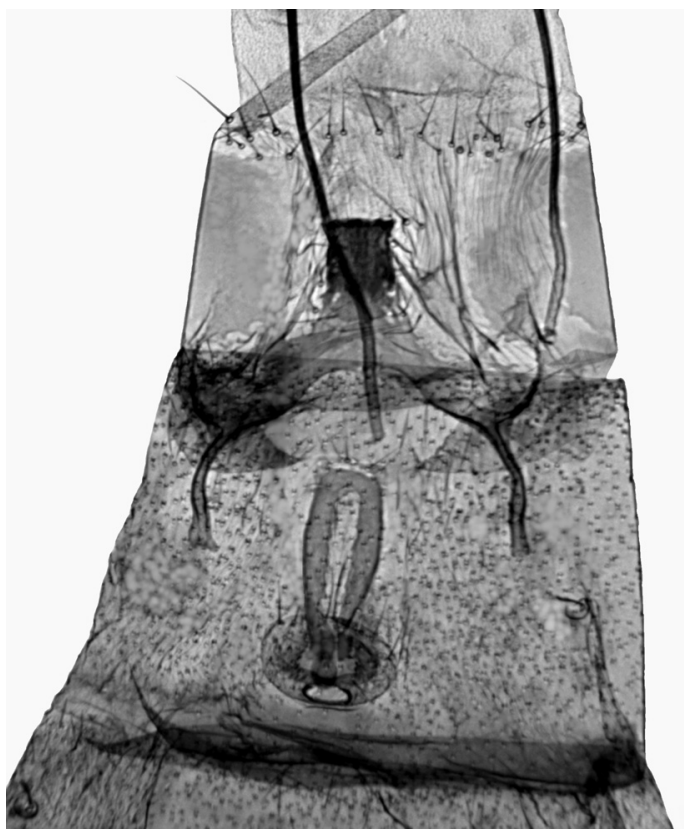

Fig. 37. Female genitalia of Scythris potatorella sp. n. (paratype).

\section{Scythris sibirella Sinev, 2001}

Russia, S-Buryatia, $51^{\circ} 11-13^{`} \mathrm{~N} 106^{\circ} 10-12^{`} \mathrm{E}, 700 \mathrm{~m}$, Hamar Daban Mountains, Murtoy river, Gusinoe ozero village $6 \mathrm{~km} \mathrm{NW}$, forest steppe, 1 ㅇ 19.VI.2002, K. Nupponen leg. Genitalia slide: K. Nupponen prep. no. 2/08.X.2002.

Distribution. Russia (Jakutia, Baikal region, Krasnojarskij kraj).

\section{Scythris sinevi sp. $\mathrm{n}$.}

Type material. Holotype: $0^{7}$ (Fig. 38): Russia, SBuryatia, $51^{\circ} 37^{\prime} \mathrm{N} 106^{\circ} 46^{\prime} \mathrm{E}, 600 \mathrm{~m}$, Hamar Daban Mountains, bolshoi Sanzheevka river, Kharamsha village $2 \mathrm{~km} \mathrm{~W}$, forest steppe, 27.VI.2002, K. Nupponen leg. In coll. T. \& K.

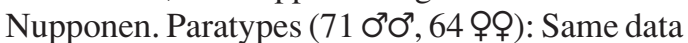
as holotype, except for dates: $430^{7} 0^{7} 44$ 우 27.VI.2002, 10 రొం $^{7} 15$ 우 28.VI.2002. Russia, S-Buryatia, $51^{\circ} 11-13^{\prime} \mathrm{N} 106^{\circ} 10-12^{\prime} \mathrm{E}, 700 \mathrm{~m}$, Hamar Daban Mountains, Murtoy river, Gusinoe ozero village $6 \mathrm{~km} \mathrm{NW}$, forest steppe, 13 व $^{7} \sigma^{7} 3$

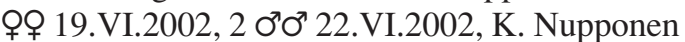
leg. $10^{\top}$ Russia, S-Buryatia, 50 58-59`N $106^{\circ} 38-$ 40 E, 550-600 m, Chikoy valley, Novoselenginsk village $10 \mathrm{~km} \mathrm{~S}$, sand dunes/sandy steppe, 


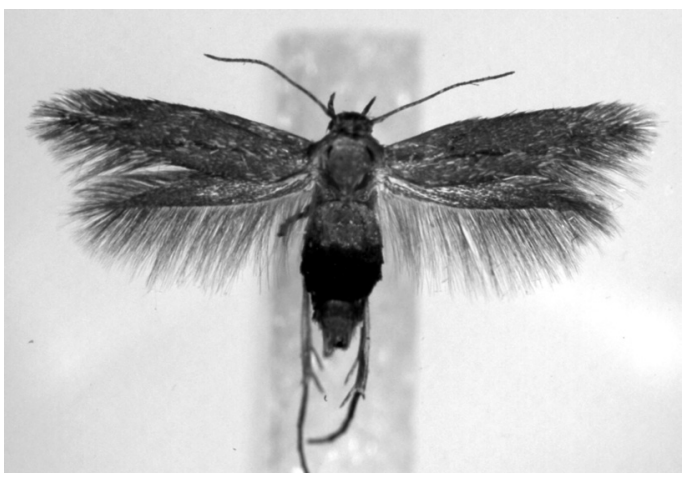

Fig. 38. Imago (holotype) of Scythris sinevi sp. n.

24.VI.2002, K. Nupponen leg. 1 Ơ $^{7}$ \& Russia, SBuryatia, Ulan-Ude $10 \mathrm{~km} \mathrm{~W}$, near Gurulba village, meadow/steppe, $700 \mathrm{~m}, 29$. VI.2002, K. Nupponen leg. $10^{7}$ Mongolia, Southern Gobi aimak, 8 km NNE Khan-Bogdo, 17.VI.1971, Kerzhner \& Chogsomzhav leg. 1 ㅇ Mongolia, Central aimak, northern slope of Bogdo-Ula Mt. Near Ulan Bator, 22.VI.1967, Kerzhner leg. Genitalia slides: K. Nupponen prep. no. 3/03.X.2002 $\left(0^{7}\right), 8 / 04 . X .2002$ (P). Five further genitalia preparations preserved in glycerol. Paratypes in the collections of T. \& K. Nupponen, Bengt Å. Bengtsson, Zoological Institute, St. Petersburg and Finnish Museum of Natural History, University of Helsinki.

Diagnosis. S. sinevi sp. n. may be confused with many small, dark scythridids. Examination of the genitalia is necessary for safe determination. The male genitalia are similar to those of $S$. hamatella K. \& T. Nupponen, 2001, but can be separated from that by the following characters: longer and more slender, distally widened gnathos, valvae of constant width, and tergum VIII with slightly incised posterior margin and lateral process widened apically. The female genitalia are similar to those of $S$. malozemovi sp. n., but sclerotized tip of sterigma is broader and larger, and medioposterior incision of sternum VII is without sclerotization at 'bottom'.

Description. Wingspan 8-9.5 mm. Head, antenna, collar, tegula and thorax dark brown, slightly glossy. Neck tuft brown with a few dirty whitish and pale ochreous scales. Labial palp: segment I whitish; segment II and III dark brown, more (segment II) or less (segment III) mixed with dirty whitish scales. Haustellum dark brown, lat-

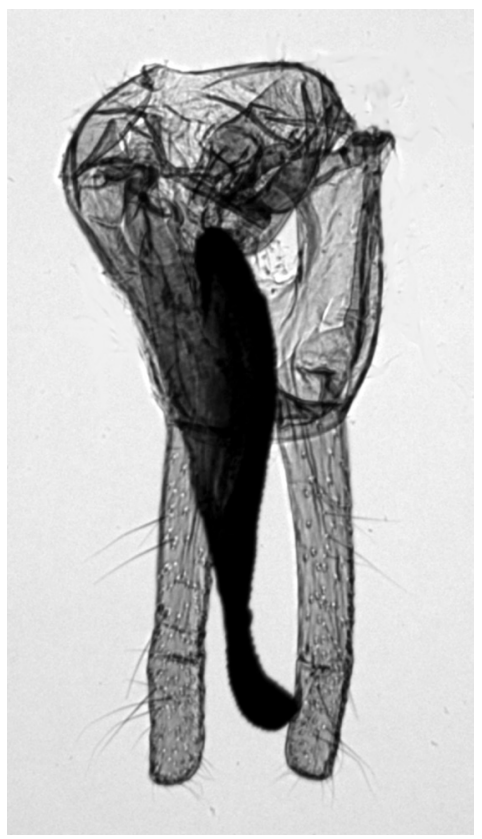

Fig. 39. Male genitalia of Scythris sinevi sp. n. (paratype).

erally dirty whitish. Forelegs and midlegs dark brown, more (femur) or less (tibia and tarsus) mixed with dirty whitish scales; hindlegs pale ochreous, tarsus darker. Abdomen dorsally dark fuscous, ventrally dirty whitish with a few pale brown and ochreous scales. Forewing dark brown with slight purplish hue; a few paler scales in fold and at apex. Hindwing dark fuscous.

Male genitalia (Figs. 39-40). Uncus reduced. Gnathos asymmetrical, long and sclerotized; basal part moderately wide, evenly tapered up to 0.9 ; distal 0.1 bent and widened, tip blunt; sclerotized part shallowly furrowed. Tegumen extended leftposteriorly. Aedeagus short and thick, distally bent and tapered. Valvae basally fused, long, of constant width, apex cut-off. Sternum VIII rectangular, twice as wide as high; posterior margin weakly sclerotized. Tergum VIII subtriangular; distally sclerotized, asymmetrical, posterior margin slightly concave; lateral margins medially with roundish extension; one lateral process reduced, another one robust, sclerotized, apex cut-off.

Female genitalia (Fig. 41). Sterigma triangular, anterior corners slightly elongate; posterior part strongly sclerotized, triangular, tip semitransparent and blunt. Sternum VII quadrangu- 


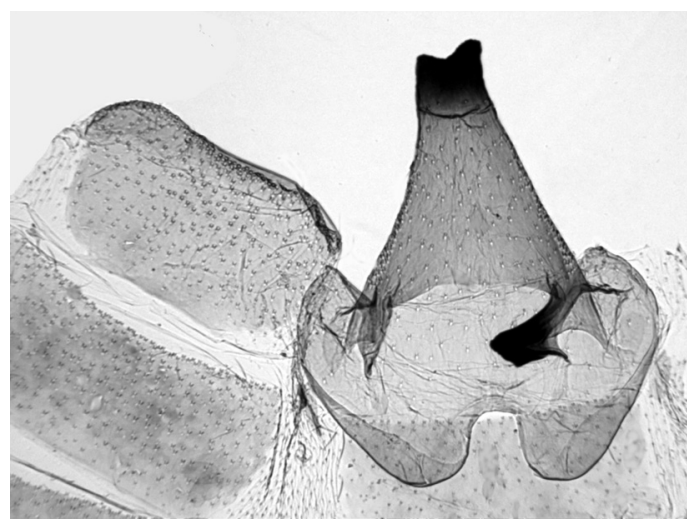

Fig. 40. Tergum VIII (right) and sternum VIII (left) of Scythris sinevi sp. n. (paratype).

lar; posterior margin with wide U-shaped medial incision; 'bottom' of incision without sclerotization. Apophyses anteriores 0.4 length of apophyses posteriores.

Bionomy. The specimens were collected in late June. The species is common in dry Artemisia steppes. The biology is unknown.

Distribution. Russia (S Buryatia), Mongolia.

Etymology. This species is dedicated to Dr. Sergey Sinev, the author of several important articles on Siberian Scythrididae.

Remarks. S. sinevi sp. n. belongs to the complex of species treated in Remarks of $S$. gorbunovi sp. n. (see above).

\section{Scythris sp. 1}

Material. Russia, S-Buryatia, 51 $11-13^{\prime} \mathrm{N}$ 106¹0-12`E, 700 m, Hamar Daban Mountains, Murtoy river, Gusinoe ozero village $6 \mathrm{~km} \mathrm{NW}$, forest steppe, 1 \& 19.VI.2002, K. Nupponen leg. Genitalia slide: K. Nupponen prep. no. 1/08.X.2002.

Female genitalia (Fig. 42). Sterigma basically U-shaped, anterior corners extended; shanks apically with extension having ragged edge. Sternum VII quadrangular; posterior margin medially incised and with narrow membranous extension. Apophyses anteriores 0.5 length of apophyses posteriores.

Remarks. A single female that is impossible to assign to any known species, neither by the external appearance nor by the characters in the female genitalia. Wingspan of the specimen is

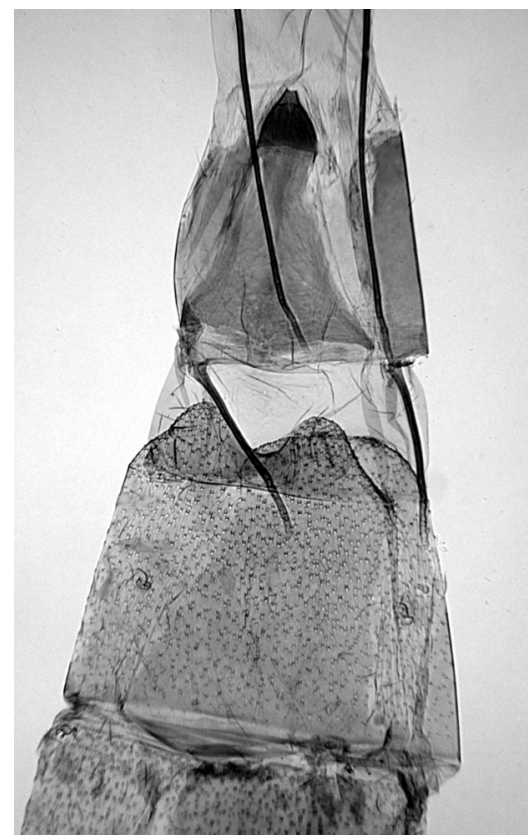

Fig. 41. Female genitalia of Scythris sinevi sp. n. (paratype).

$11 \mathrm{~mm}$, and forewings are dark brown with a few white scales in fold. Although this taxon is probably undescribed, I refrain from describing a new species for the present until more material including males is available for study.

\section{Scythris sp. 2}

Material (Fig. 43). Russia, S-Buryatia, 5111$13^{\prime} \mathrm{N} 106^{\circ} 10-12^{\prime} \mathrm{E}, 700$ m, Hamar Daban Mountains, Murtoy river, Gusinoe ozero village $6 \mathrm{~km}$ NW, forest steppe, 5 우 19.VI.2002, 1 우 22.VI.2002, K. Nupponen leg. Genitalia slide: K. Nupponen prep. no. 1/07.X.2002.

Female genitalia (Fig. 44). Sterigma bowllike, laterally with few setae. Sternum VII rectangular, posterior margin medially concave. Apophyses anteriores 0.7 length of apophyses posteriores.

Remarks. Wingspan 10-12.5 mm. Externally the moth resembles $S$. hamardabanica sp. n., but can be separated from that by several characters: ground colour of the forewing is fuscous (more brown in hamardabanica), abdomen dorsally fuscous without golden hue and hindleg tibia fuscous mixed with 


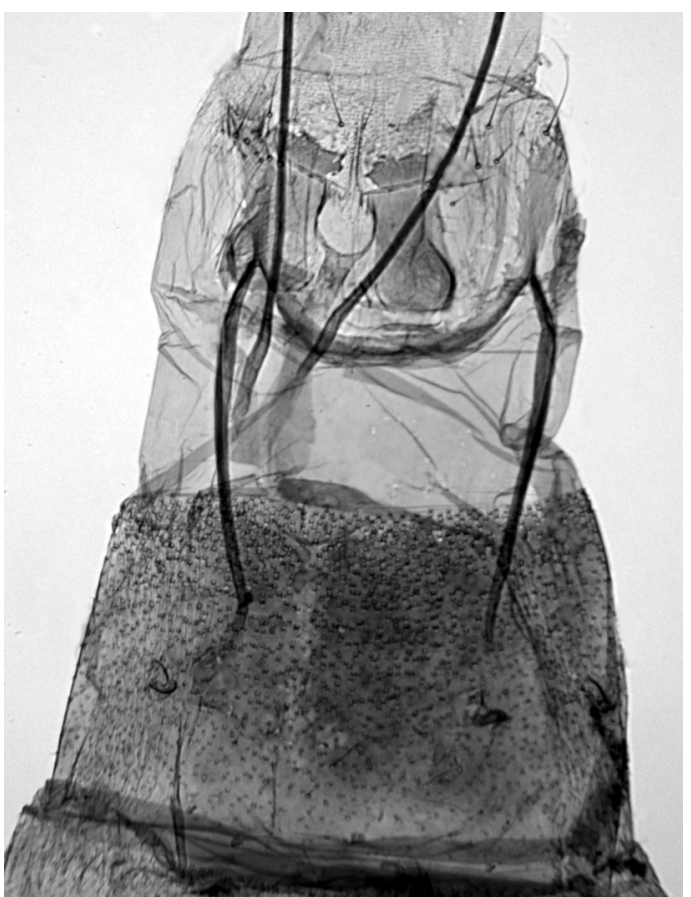

Fig. 42. Female genitalia of Scythris sp. 1.

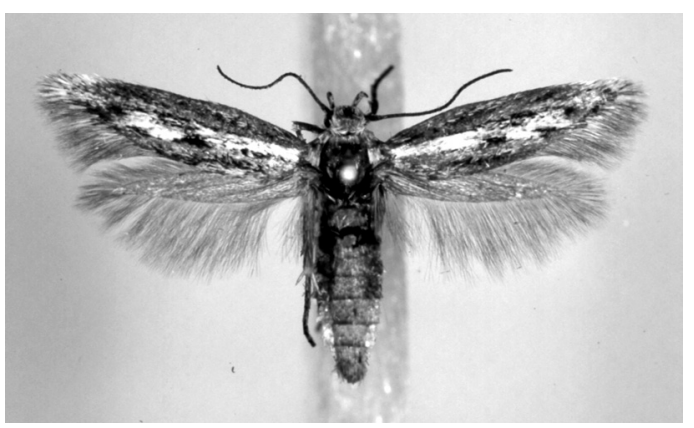

Fig. 43. Imago (female) of Scythris sp. 2.

paler scales (pale ochreous in hamardabanica). All six specimens were collected in a small spot where males of S. felixi Bengtsson \& Sutter, 1996 were abundant (see above). The external appearance of the females coincide well with that of felixi (see Fig. 8), but the genitalia are very different from those illustrated in the original description (see Bengtsson $\&$ Sutter 1996). At the moment it is impossible to assign this taxon to any known species.
Nupponen • ENTOMOL. FENNICA Vol. 14

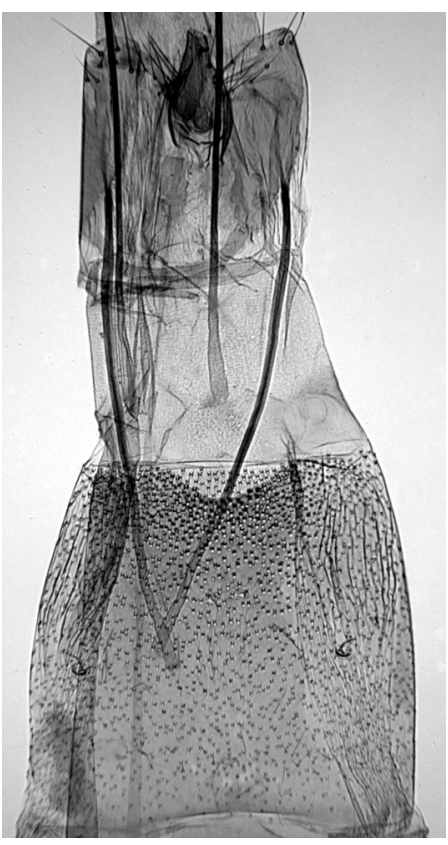

Fig. 44. Female genitalia of Scythris sp. 2.

\section{Discussion}

In addition to the 26 species reported from southern Buryatia in the present article, I was able to find in the available literature only one further scythridid species recorded from the region: $S$. inconspicuella Sinev, 2001 was found in UlanUde in mid-July, 1956 (Sinev 2001). Several additional species are known from adjacent regions in northern Buryatia, Jakutia, Tuva, Chita and northern Mongolia (Bengtsson 1997b, Bengtsson \& Liška 1996, Bengtsson \& Sutter 1996, Sachkov \& Sinev 2001, Sinev 2001a, 2001b). As I collected in Buryatia for only two weeks and in a few localities, it is expected that many new species will be discovered there in the future. Of the 26 taxa, only 5 have been recorded in Europe, and 3 additional species have the western border of their distribution range in the Ural Mountains. Thus, the eastern Palaearctic fauna dominates in southern Buryatia. It may be that the high mountain ranges mainly covered by taiga forests (Altai, Sayan, Hamar Daban) and the Lake Baikal form a barrier for western Palaearctic species, effectively 
preventing the scythridids from extending their distribution range to the east.

Good habitats for scythridids - primary steppes and rocky slopes - are scarce in the region studied. Steppes are restricted to river valleys while slopes at higher elevations are covered by forests. Large areas have been destroyed by agricultural influence and foothill steppes are often used for pasturage. I managed to find only three localities in good condition, each of them having a very rich fauna of Scythrididae. One of them is located close to a sacred place and the local people did not keep cattle there. Further investigation of similar habitats will surely yield interesting results.

As a conclusion, the scythridid fauna in the eastern Palaearctic steppe regions is very rich but poorly known, and many unknown taxa are still waiting to be discovered.

Acknowledgements. I thank Dr. Vladimir Olschwang (Ekaterinburg, Russia) for organizing the expedition to Buryatia. My thanks are also due to the following persons for guide services, assistance, company or other kind of help: Mr. Bengt Å. Bengtsson (Färjestaden, Sweden), Mr. Pavel Gorbunov (Ekaterinburg, Russia), Dr. Lauri Kaila (Helsinki, Finland), Mr. Yuri Karpov (Sludjanka, Russia), Dr. Pavel Kulikov (Ekaterinburg, Russia), Mr. Alexander Malozemov (Ekaterinburg, Russia), Mrs. Elena Nupponen (Espoo, Finland), Mr. Timo Nupponen (Espoo, Finland), Mr. Yuri Shevnin (Ekaterinburg, Russia), Dr. Pasi Sihvonen (Helsinki, Finland), Dr. Sergey Sinev (St. Petersburg, Russia). Finally, I thank Mr. Kimmo Silvonen (Espoo, Finland) for his help in processing the photographs of imagos as well as the Lepidopterological Society of Finland for a grant that helped to organize the expedition.

\section{References}

Bengtsson, B. Å. 1997a: Scythrididae. — In: Huemer, P., Karsholt, O. \& Lyneborg, L. (eds.), Microlepidoptera of Europe 2: 1-301.

Bengtsson, B. A. 1997b: Notes on interesting scythridids in the Zoological Museum, Helsinki, Finland (Lepidoptera, Scythrididae). — Entomol. Fennica 8: 89-102.

Bengtsson, B. Å. \& Liška, J. 1996: Notes on Asian scythridids with description of four new species (Lepidoptera, Scythrididae). - Phegea 24: 33-39.

Bengtsson, B. Å. \& Sutter, R. 1996: Scythris felixi sp. n. (Insecta, Lepidoptera: Scythrididae) aus der Mongolei. — Reichenbachia Mus. Tierk. Dresden 31, Nr. 37: 207 208.

Chrétien, P. 1900: Description d'une nouvelle espèce de Microlépidoptère de France. - Bull. Soc. ent. Fr. 1900: 162-163.

Nupponen, K., Bengtsson, B. Å., Kaitila, J.-P., Nupponen, T., Junnilainen, J. \& Olschwang, V. 2000: The scythridid fauna of the southern Ural Mountains, with description of fourteen new species (Lepidoptera: Scythrididae). - Entomol. Fennica 11: 5-34.

Nupponen, K. \& Nupponen, T. 2001: Notes on the scythridid fauna of the Altai Mountains, with description of four new species (Lepidoptera: Scythrididae). — Entomol. Fennica 12: 81-93.

Sachkov, S. A. \& Sinev, S. Y. 2001: A new species of the genus Scythris Hbn. (Lepidoptera, Scythrididae) from Transbaikalia. - Proceedings of the Zoological Institute, St. Petersburg, vol. 291: 27-30. [In Russian].

Sinev, S. Y. 2001a: New and little-known species of the genus Scythris Hbn. (Lepidoptera, Scythrididae) from the Asiatic part of Russia. - Proceedings of the Zoological Institute, St. Petersburg, vol. 291: 3-26. [In Russian].

Sinev, S. Y. 2001b: Family Scythrididae. - In: Key to the insects of Russian Far East, vol. V, Trichoptera and Lepidoptera 3: 473-487. [In Russian]. 